\title{
The contribution of boundary layer nucleation events to total particle concentrations on regional and global scales
}

\author{
D. V. Spracklen ${ }^{1, *}$, K. S. Carslaw ${ }^{1}$, M. Kulmala ${ }^{2}$, V.-M. Kerminen ${ }^{3}$, G. W. Mann ${ }^{1}$, and S.-L. Sihto ${ }^{2}$ \\ ${ }^{1}$ School of Earth and Environment, University of Leeds, UK \\ ${ }^{2}$ University of Helsinki, Department of Physical Sciences, P.O. Box 64, 00014 University of Helsinki, Finland \\ ${ }^{3}$ Finnish Meteorological Institute, Climate and Global Change, Erik Palmenin aukio 1, P.O. Box 503, 00101 Helsinki, Finland \\ *now at: Atmospheric Chemistry Modelling Group, Harvard University, Cambridge, MA, USA
}

Received: 14 June 2006 - Published in Atmos. Chem. Phys. Discuss.: 3 August 2006

Revised: 10 November 2006 - Accepted: 1 December 2006 - Published: 18 December 2006

\begin{abstract}
The contribution of boundary layer (BL) nucleation events to total particle concentrations on the global scale has been studied by including a new particle formation mechanism in a global aerosol microphysics model. The mechanism is based on an analysis of extensive observations of particle formation in the BL at a continental surface site. It assumes that molecular clusters form at a rate proportional to the gaseous sulfuric acid concentration to the power of 1 . The formation rate of $3 \mathrm{~nm}$ diameter observable particles is controlled by the cluster formation rate and the existing particle surface area, which acts to scavenge condensable gases and clusters during growth. Modelled sulfuric acid vapour concentrations, particle formation rates, growth rates, coagulation loss rates, peak particle concentrations, and the daily timing of events in the global model agree well with observations made during a 22-day period of March 2003 at the SMEAR II station in Hyytiälä, Finland. The nucleation bursts produce total particle concentrations ( $>3 \mathrm{~nm}$ diameter) often exceeding $10^{4} \mathrm{~cm}^{-3}$, which are sustained for a period of several hours around local midday. The predicted global distribution of particle formation events broadly agrees with what is expected from available observations. Over relatively clean remote continental locations formation events can sustain mean total particle concentrations up to a factor of 8 greater than those resulting from anthropogenic sources of primary organic and black carbon particles. However, in polluted continental regions anthropogenic primary particles dominate particle number and formation events lead to smaller enhancements of up to a factor of 2 . Our results therefore suggest that particle concentrations in remote continental regions are dominated by nucleated particles while concentrations in polluted continental regions are dominated by primary particles. The effect of BL particle formation over tropical regions and the Amazon is negligi-
\end{abstract}

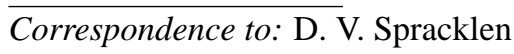

(dominick@env.leeds.ac.uk) ble. These first global particle formation simulations reveal some interesting sensitivities. We show, for example, that significant reductions in primary particle emissions may lead to an increase in total particle concentration because of the coupling between particle surface area and the rate of new particle formation. This result suggests that changes in emissions may have a complicated effect on global and regional aerosol properties. Overall, our results show that new particle formation is a significant component of the aerosol particle number budget.

\section{Introduction}

Changes in the properties of atmospheric aerosol particles exert a considerable effect on climate through their effect on atmospheric opacity and cloud properties. The effect of aerosols on climate is controlled by several physical and chemical properties but key among them is the particle size distribution (Dusek et al., 2006). It is now recognised that global climate models need to be able to predict changes in the particle size distribution in order to capture aerosol climatic effects realistically, and several chemical transport and climate models have recently been developed with this level of sophistication (Adams and Seinfeld, 2002; Vignati et al., 2004; Stier et al., 2005; Spracklen et al., 2005a, b). However, global calculation of the size distribution requires a model that includes particle number concentration as a prognostic variable. Particle number is one of the most challenging quantities to predict on a global scale because it depends on processes affecting formation, growth and removal of particles from nanometre sizes upwards. Despite the importance of particle number, global models contain mostly rudimentary representations of particle formation and very little effort has been devoted to testing formation schemes against observations, assessing their realism, or exploring the ways in which formation processes might affect the climate.

Published by Copernicus GmbH on behalf of the European Geosciences Union. 
The comprehensive review of more than 100 individual investigations by Kulmala et al. (2004a) shows that nm-sized particle formation "bursts" occur at a large number of sites around the world. These observations demonstrate the importance of particle formation for local particle concentrations, the particle size distribution, and cloud condensation nuclei (Lihavainen et al., 2003; Kerminen et al., 2005). The upper troposphere is well recognised as a region of particle formation, but extensive observations have also been made in the atmospheric boundary layer (BL) (Kulmala et al., 2004a). New particle formation in the BL has been observed at locations ranging from Antarctica (Koponen et al., 2003), subArctic Lapland (Vehkamäki et al., 2004), the remote boreal forest (Mäkelä et al., 1997; Dal Maso et al., 2005), suburban and industrialised regions (Birmili and Wiedensohler, 2000; Birmili et al., 2000; Gaydos et al., 2005; Laaksonen et al., 2005), and in coastal environments around Europe (O'Dowd et al., 1999). The formation events can produce particle concentrations of up to $10^{4}$ or $10^{5} \mathrm{~cm}^{-3}$ for several hours around local midday (Kulmala et al., 2004a). These newly formed particles have been observed to grow to sizes sufficient to act as cloud condensation nuclei (Lihavainen et al., 2003; Laaksonen et al., 2005), and eventually to form cloud droplets (Kerminen et al., 2005), so there is direct evidence that particle formation could affect the climate. A number of sites have several years of measurements from which the seasonal variation in the frequency of formation events has been deduced, as well as the environmental factors that affect formation and growth rates of the nucleated particles.

Despite the documented importance of BL particle formation for aerosol on local and regional scales, no concerted effort has been made to include the process in global models in a realistic way. The particle formation rate observed in the BL greatly exceeds the binary homogeneous nucleation (BHN) rate of sulfuric acid particle formation (Kulmala et al., 1998; Vehkamäki et al., 2002) that has been used in some global aerosol models (e.g., Von Salzen et al., 2000; Stier et al., 2005; Spracklen et al., 2005a, b). Other studies on the regional and global scale have used a nucleation scheme developed by Kerminen and Wexler (1994) for formation of $\mathrm{H}_{2} \mathrm{SO}_{4}-\mathrm{H}_{2} \mathrm{O}$ particles. This scheme has also been used in regional particulate models (e.g., Binkowski and Shankar, 1995) and in a different form in the widely used Models-3 Community Multiscale Air Quality (CMAQ) Modelling System (e.g., Yu et al., 2003). Typically, it is assumed that $\mathrm{H}_{2} \mathrm{SO}_{4}-\mathrm{H}_{2} \mathrm{O}$ particle formation occurs when the $\mathrm{H}_{2} \mathrm{SO}_{4}$ vapour concentration exceeds a threshold value determined by the thermodynamic parameterisation of JaeckerVoirol and Mirabel (1989), although an assumption needs to be made about the size of the particles in order to determine their number.

Nucleation processes are not the only way that high concentrations of particles enter the lower atmosphere. Primary particles emitted from natural processes and anthropogenic activities can account for a large fraction of total observ- able particles (condensation nuclei, $\mathrm{CN}$, defined here to be all particles larger than $3 \mathrm{~nm}$ diameter.) However, global models that include primary natural and anthropogenic emissions fail to capture the very high total particle concentrations that are observed over some continental locations. For example, in the global aerosol model study of Stier et al. (2005) predicted $\mathrm{CN}$ concentrations in the continental BL were substantially lower than observed. Their model included emissions of black carbon and organic carbon from combustion sources. CN concentrations over Europe were typically predicted to be $\sim 1000 \mathrm{~cm}^{-3}$, while the observations of Schroder et al. (2002) and Petzold et al. (2002) showed a mean of $7000 \mathrm{~cm}^{-3}$. Such high CN concentrations are typical of longterm measurements over the European continent.

There are several factors that have limited investigations of particle formation to case studies using box models. Firstly, the contribution of secondary aerosol formation to particle concentrations is very difficult to simulate in a large scale model. Particles enter the atmosphere at sizes less than $1 \mathrm{~nm}$ and concentrations of as high as $10^{7} \mathrm{~cm}^{-3}$, but they affect atmospheric opacity and cloud formation only once they have grown to $>50 \mathrm{~nm}$ diameter (a factor $>10^{5}$ increase in volume). During the time taken to grow to this size (within $\sim$ hours to days) atmospheric processes reduce the particle concentration by several orders of magnitude. Accurate calculations of the net contribution of secondary particles to the climate-relevant size range of $>50 \mathrm{~nm}$ therefore requires a model that includes a full aerosol microphysics scheme and a representation of particle number concentrations down to nanometre sizes. Secondly, the processes that control nucleation are not understood completely and, even when good observations exist, it has been difficult to parameterise formation rates for use in large scale models. Thirdly, until recently, long-term observations of particle formation have not been available, making it very difficult to understand the processes and conditions controlling formation.

Two major developments in recent years now make the inclusion of aerosol nucleation in global models a realistic prospect. First, detailed microphysical and chemical aerosol processes are now included in some global models (e.g., Adams and Seinfeld, 2002; Ghan et al., 2001; Gong et al., 2003; Rodriguez and Dabdub, 2004; Spracklen et al., 2005a, b; Stier et al., 2005) and, as we show here, these can readily be extended to include a source of particles at nanometre sizes. Secondly, analysis of observations from several global locations (Kulmala et al., 2004a) has led to the development of particle formation mechanisms that are able to quantitatively explain many features of the observations (e.g., nanoparticle activation theory by Kulmala et al., 2004b; or cluster activation theory by Kulmala et al., 2006). Although our understanding of what controls particle formation in the atmospheric BL is still developing, the success of these schemes in explaining observations is sufficiently good that an attempt to simulate formation on large scales can now be made. 
The purpose of this study is to provide a first estimate of the effect of BL particle formation on the total particle number concentration budget. It is an advance on previous global model studies because we use a particle formation parameterisation that has been developed specifically to explain long-term observations of formation events. We also aim to quantify the relative contribution of primary and secondary (nucleated) particles to BL concentrations, while previous studies have focussed only on the formation events themselves and not on the wider effects. Although observations suggest that particle formation contributes locally to high particle concentrations, we do not know what fraction of the "background" particle concentration comes from primary emissions and what fraction is formed through nucleation. Such fundamental information on the sources of atmospheric particles is required for the development of accurate models of the global aerosol and the effect on climate.

Our approach is to use a global 3-D aerosol microphysics model. The advantage of such a large scale model over a box or regional-scale model is that the predicted particle concentration, size distribution, and controlling parameters like particle surface area and precursor gas concentrations at any location are affected not only by local emissions and formation, but also by long-range transport and down-mixing from the particle-rich upper troposphere. Here we show that although the upper troposphere is a rich source of new particles, its contribution to particle concentrations in the $\mathrm{BL}$ is likely to be small except over oceanic regions. We can also use the global coverage of the model to identify regions where new particle formation may be important to the concentration budget and explore some of the factors that might determine changes. However, it needs to be borne in mind that although our nucleation mechanism captures some important observed features of BL formation events in different environments, the reliability of global predictions requires careful evaluation in the future.

This is the first study to focus on particle formation and its contribution to the large scale particle number budget. We restrict our analysis to $\mathrm{CN}$. A fuller analysis of the effects on the size distribution and the cloud condensation nucleus $(\mathrm{CCN})$ budget will be part of a follow-up study.

\section{Model description}

We use the Global Model of Aerosol Processes (GLOMAP) (Spracklen et al., 2005a, b). GLOMAP is an extension to the TOMCAT global 3-D off-line chemical transport model (CTM) (Chipperfield et al., 1993; Stockwell and Chipperfield, 1999). It represents the aerosol distribution using size sections (bins) with 2 moments simulated per section (mass per particle and number concentration in a section). 20 bins spanning dry diameters from about $3 \mathrm{~nm}$ to $25 \mu \mathrm{m}$ are used here, with bin sizes increasing as a volume ratio. The timedependent equations describing aerosol nucleation, conden- sation, growth, coagulation, wet and dry deposition, transport, and cloud processing are calculated using an operatorsplitting technique. In these simulations we use a spatial resolution of $2.8^{\circ} \times 2.8^{\circ}$ with 31 hybrid $\sigma$-p levels extending from the surface to $10 \mathrm{hPa}$, with the lowest layers centered at about $30 \mathrm{~m}, 140 \mathrm{~m}, 340 \mathrm{~m}, 600 \mathrm{~m}, 930 \mathrm{~m}, 1300 \mathrm{~m}, 1710 \mathrm{~m}$ above the surface.

Large-scale atmospheric transport is specified from European Centre for Medium-Range Weather Forecasts (ECMWF) analyses at 6-hourly intervals. Tracer advection is performed using the scheme of Prather (1986) and subgrid transport is calculated using the convection scheme of Tiedtke (1989). Turbulent mixing in the BL and BL height are calculated using the paramaterization of Holtslag and Boville (1993). A comparison of model BL height with observations is given by Wang et al. (1999). They show that calculated BL height is in good agreement with Holtslag and Boville (1993) and that including the scheme results in an improved seasonal cycle of model tracers.

BL clouds are specified on a monthly mean basis from the International Satellite Cloud Climatology Project (ISCCP) archive. In these clouds, the aerosol is processed $\left(\mathrm{SO}_{2}\right.$ reacted to form particulate sulfate) but no precipitation removal of gases or particles is assumed to occur. In these simulations we use a fixed dry diameter of $50 \mathrm{~nm}$ above which particles are assumed to form cloud drops. This simple scheme does not take into account variability in aerosol activation that depends on aerosol size distribution (Dusek et al., 2006), aerosol composition (VanReken et al., 2005) or cloud updraught velocity. Convective and frontal clouds are assumed to remove gases and aerosols through nucleation scavenging (drop formation) and below-cloud impaction scavenging. Spracklen et al. (2005a, b) showed that GLOMAP is capable of simulating realistic marine boundary layer (MBL) $\mathrm{CN}$ and $\mathrm{CCN}$ concentrations.

\subsection{Particle types}

In this study we include sulfate, sea salt, black carbon (BC) and organic carbon (OC) particles. Secondary sulfate particles are formed through binary homogeneous nucleation above the BL (Kulmala et al., 1998; Spracklen et al., 2005a) as well as through particle formation within the BL. For a description of the particle formation mechanisms used in the model see Sect. 2.2. Sea salt, BC and OC are emitted as primary particles. Growth of all particles can occur through the condensation of both sulfuric acid vapour and a condensable secondary organic species (see Sect. 2.2), as well as through addition of sulfate mass for those particles large enough to be activated in clouds. The emissions of gas phase and particulate species are summarised in Table 1.

The computational cost of simulating this number of different particles and their mixtures across 20 size sections is minimised by making some simplifying assumptions. The principal assumption we have made is to treat all particles 


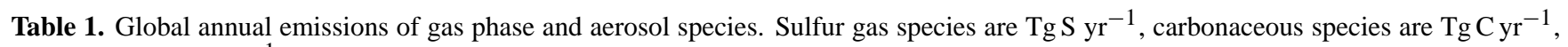
sea salt is $\mathrm{Tg} \mathrm{NaCl} \mathrm{yr}^{-1}$.

\begin{tabular}{llll}
\hline Species & Source & Reference & $\begin{array}{l}\text { Source } \\
\text { Strength/Tg yr }\end{array}$ \\
& & & 18.7 \\
\hline DMS & Oceans & Kettle et al. (1999) & 54.3 \\
$\mathrm{SO}_{2}$ & Industry, Fossil Fuels, Bio-fuels & Cofala et al. (2005) & 12.6 \\
& Volcanoes & Andres and Kasgnoc (1998) & 127.0 \\
Monoterpenes & Biogenic & Guenther et al. (1995) & 12.0 \\
BC & Vegetation fires & Van der Werf et al. (2003) & 3.0 \\
& Fossil Fuels & Bond et al. (2004) & 3.0 \\
\multirow{2}{*}{ Primary OC } & Bio-fuels & Bond et al. (2004) & 1.6 \\
& Vegetation Fires & Van der Werf et al. (2003) & 24.8 \\
& Fossil Fuels & Bond et al. (2004) & 2.4 \\
Sea Salt & Bio-fuels & Bond et al. (2004) & 6.5 \\
\hline
\end{tabular}

as if they have the same composition - that of acidic sulfate. There are a number of effects of this assumption that can be approximately quantified. Firstly, BC and OC particles do not grow hygroscopically like sulfate particles, so any size dependent processes affecting their number concentration will be different. The most important effect of this will be to artificially increase the particle scavenging efficiency in clouds (through drop formation on the more hygroscopic acidic particles). However, complete removal of in-cloud scavenging increased CN globally by only $10 \%$, so our assumption had an insignificant effect on our results.

Emissions of black and primary organic matter from fossil fuel and bio-fuel burning (Bond, 2004) and biomass burning (van der Werf et al., 2003) are new components of GLOMAP since the studies of Spracklen et al. (2005a, b), so they are briefly described here. Emission databases give monthly mean emissions at a resolution of $1^{\circ} \times 1^{\circ}$. Primary organic matter is assumed to have a total mass of 1.4 times that of the carbon mass fraction (Dentener et al., 2006). Primary particles are emitted as lognormal modes that are then mapped to the model's size sections. The number mode radius is 0.04 and $0.015 \mu \mathrm{m}$ for biomass and fossil fuel, respectively. Standard deviation for both modes is 1.8. Fossil fuel and bio-fuel emissions are added to the lowest model layer. Vegetation fire emissions are emitted between the surface and $6 \mathrm{~km}$ altitude as described by the AEROCOM emissions inventory.

Adams and Seinfeld (2002) and Spracklen et al. (2005b) have shown that a small fraction of anthropogenic sulfur emitted as particulates can have a large effect on $\mathrm{CN}$ and $\mathrm{CCN}$ concentrations in polluted regions. However, the fraction of anthropogenic sulfur that is emitted directly as particulates is very uncertain. Here, we assume that the only primary emissions are of $\mathrm{BC}, \mathrm{OC}$ and sea salt, and assume that all new sulfate particles are formed from nucelation of gas-phase sulfuric acid.

\subsection{Particle formation mechanism}

Observations show that $\mathrm{BL}$ particle formation depends on $\mathrm{H}_{2} \mathrm{SO}_{4}$ vapour concentration to the power 1 to 2 (e.g., Weber et al., 1996; Kulmala et al., 2006; Sihto et al., 2006). This observed relatively weak dependence on $\mathrm{H}_{2} \mathrm{SO}_{4}$ is in contrast to the dependence on $\mathrm{H}_{2} \mathrm{SO}_{4}$ to the power $>10$ expected for thermodynamic binary nucleation involving sulfuric acid and water (Kulmala et al., 1998; Vehkamäki et al., 2002) and values between 5 and 10 for ternary (sulfuric acid/ammonia/water) nucleation (Napari et al., 2002). The mechanistic understanding of this dependence has been explored by Kulmala et al. (2006), who suggest that a dependence on $\left[\mathrm{H}_{2} \mathrm{SO}_{4}\right]^{1}$ could be understood in terms of activation of molecular clusters. The nucleation rate in such a mechanism can be described by

$J^{*}=k\left[\mathrm{H}_{2} \mathrm{SO}_{4}\right]$

where $J^{*}$ is the formation rate of clusters. The rate constant $k$ contains the detail of the cluster activation process, but currently the processes governing cluster formation and activation are poorly understood. The rate constant may be a function of several parameters, such as temperature, humidity and the abundance of certain organic compounds. Gaydos et al. (2005) have also shown that in some environments gas phase ammonia may be a limiting species in the formation of new particles. Their study focussed on the highly polluted region of Pittsburgh (Eastern U.S.) where ammonia concentrations are lower than $\mathrm{H}_{2} \mathrm{SO}_{4}$. In the absence of such mechanistic understanding, we have used a value of $k$ $\left(2 \times 10^{-6} \mathrm{~s}^{-1}\right)$ determined empirically (Kulmala et al., 2006; Sihto et al., 2006). We also show results for different values of $k$ but we note that our limited mechanistic understanding limits the reliability of large-scale predictions in a wide range of environments. A similar approach was used in a recent 
box model study (Boy et al., 2006) assuming $J^{*}$ to depend on $\left[\mathrm{H}_{2} \mathrm{SO}_{4}\right]^{2}$.

The effective production rate of measurable ( $\sim 3 \mathrm{~nm}$ diameter) particles $\left(J_{m}\right)$ is typically much less than $J^{*}$ because of scavenging of the nucleated particles as they grow. A complete calculation of this scavenging loss requires a model with high size resolution down to the size of the molecular clusters (Lehtinen and Kulmala, 2003; Tammett and Kulmala, 2005). Such a computationally demanding approach is not feasible in a global model. However, Kerminen and Kulmala (2002) have shown that an approximate analytical solution to the problem can be obtained by making some assumptions. They have shown that the effective production rate of measurable particles can be expressed in terms of $J^{*}$ as

$$
J_{m}=J^{*} \exp \left\{0.23\left(\frac{1}{d_{m}}-\frac{1}{d^{*}}\right) \frac{\mathrm{CS}^{\prime}}{\mathrm{GR}}\right\}
$$

where $d(\mathrm{~nm})$ is the diameter of the particle, $\mathrm{CS}^{\prime}$ is the reduced condensation sink $\left(\mathrm{m}^{-2}\right)$ and GR is the growth rate $\left(\mathrm{nm} \mathrm{h}^{-1}\right)$ of the clusters, which is assumed to be constant between $d^{*}$ and $d_{m}$. Here we assume that $d^{*}=1 \mathrm{~nm}$ and $d_{m}=3 \mathrm{~nm}$. In this case, Eq. (2) reduces to

$$
J_{3}=J_{1} \exp \left\{-0.153 \frac{\mathrm{CS}^{\prime}}{\mathrm{GR}}\right\}
$$

The reduced condensation sink $\left(\mathrm{CS}^{\prime}\right)$ is calculated by summing over the aerosol size bins $\mathrm{j}$

$$
\mathrm{CS}^{\prime}=\sum_{j} \beta_{j} r_{j} N_{j}
$$

where $\beta_{j}$ is the transitional correction for the condensational mass flux (Fuchs and Sutugin, 1971), $r_{j}$ is the particle radius and $N_{j}$ is the particle number. The condensation sink (CS) has units of $s^{-1}$ and is calculated from the reduced condensation sink by

$$
\mathrm{CS}=4 \pi \mathrm{DCS}^{\prime}
$$

where $\mathrm{D}$ is the vapour diffusion coefficient.

Growth rate between 1 and $3 \mathrm{~nm}$ is calculated using the following approximation from Kerminen and Kulmala (2002)

$\mathrm{GR}=\frac{3.0 \times 10^{-9}}{\rho_{\mathrm{nuc}}} \sum_{i} c_{i} M_{i} C_{i}$

where index $i$ goes over condensable vapours and $C_{i}$ is gasphase concentration (molecules $\mathrm{cm}^{-3}$ ), $c_{i}$ is molecular speed of condensing vapour $\left(\mathrm{m} \mathrm{s}^{-1}\right)$ and $M_{i}$ is its molecular weight $\left(\mathrm{kg} \mathrm{mol}^{-1}\right)$ and $\rho_{\text {nuc }}$ is nuclei density $\left(\mathrm{kg} \mathrm{m}^{-3}\right)$.

In reality, growth rates may be size dependent due to a contribution from organics (Kulmala et al., 2004b; Hirsikko et al., 2005). In baseline model runs, sulfuric acid vapour and oxidised biogenic organic compounds contribute to the particle growth above $3 \mathrm{~nm}$, while only sulfuric acid contributes below $3 \mathrm{~nm}$, although a sensitivity test allowing organics to contribute to GR also below $3 \mathrm{~nm}$ is discussed.

In the model, $3 \mathrm{~nm}$ diameter particles are added each time step to the first size section of the model and the gas phase sulfuric acid vapour is adjusted accordingly. The timestep in the model for this process is $3 \mathrm{~min}$. These particles then continue to coagulate with all other particles and grow by further condensation.

As can be seen from Eqs. (1) and (2), the formation rate of $3 \mathrm{~nm}$ particles is determined by two competing factors: 1) the production rate of low volatility vapours which influences both $J^{*}$ and GR, and 2) aerosol surface area (a surrogate for CS), which determines the scavenging rate of low volatility vapours and $<3 \mathrm{~nm}$ diameter particles. The importance of aerosol surface area for observable particle production is well established from observations and modelling studies although, as we show here, the dependence is not always straightforward (Mäkelä et al., 1997; Birmili et al., 2000; Kulmala et al. 2001; Gaydos et al., 2005; Dal Maso et al., 2005; Fiedler et al., 2005; McMurry et al., 2005).

The above mechanism was originally based on measurements performed at the SMEAR II Station, Hyytiälä, Finland under clean and polluted conditions. It has also been shown to be valid for particle formation taking place under more polluted lower-tropospheric conditions, such as those encountered at Heidelberg in central Europe (Fiedler et al., 2005). Both observation sets show that a high condensation sink can suppress particle formation but that high sulfuric acid concentrations allow formation to occur even when scavenging rates are high. A weak dependence on sulfuric acid vapour concentration, as assumed in our model, is also observed. The interplay between particle production rates (controlled by sulfuric acid concentrations) and loss (due to scavenging) is a common feature of particle formation in many locations, even in environments where additional controlling factors are evident (e.g., Gaydos et al., 2005). This behaviour is central to the predictions that we make here.

This nucleation mechanism is assumed to occur only in the BL. Above the BL we use the Kulmala et al. (1998) binary homogeneous nucleation rate of sulfuric acid/water particles. In Spracklen et al. (2005a) we showed that this nucleation scheme is capable of reproducing observed particle number in the free and upper troposphere. Our limited measurements above the BL at Hyytiälä and aircraft observations showing $\mathrm{CN}$ enhancements in the European BL and a minimum just above it (Schroder et al., 2002) suggest that new particle formation is confined to the BL. However, the reason for such behaviour is not understood. Application of Eq. (1) throughout the depth of the atmosphere does not restrict particle formation to the $\mathrm{BL}$, which suggests that $J^{*}$ probably depends on quantities other than $\mathrm{H}_{2} \mathrm{SO}_{4}$. Further work is needed to determine what these quantities are. 
Table 2. Reaction rates of $\alpha$-pinene.

\begin{tabular}{ll}
\hline Reaction & Rates \\
\hline $\mathrm{OH}+\alpha$-pinene & $1.2 \times 10^{-11} \exp (444 / \mathrm{T})$ \\
$\mathrm{O}_{3}+\alpha$-pinene & $1.01 \times 10^{-15} \exp (-732 / \mathrm{T})$ \\
$\mathrm{NO}_{3}+\alpha$-pinene & $1.19 \times 10^{-12} \exp (490 / \mathrm{T})$ \\
\hline
\end{tabular}

\subsection{Particle growth rates and organic condensation}

The growth of newly formed $3 \mathrm{~nm}$ particles in the model results from condensation of sulfuric acid vapour and oxidised biogenic organic compounds. There is currently considerable uncertainty regarding the sources and nature of organic compounds that can contribute to particle growth, particularly growth of nm-sized clusters.

Following Tunved et al. $(2004,2006)$ and Boy et al. (2006) we assume that a fixed fraction (here, 13\%) of biogenic monoterpene oxidation products can condense on all particles as an involatile species regardless of particle size (see Sect. 2.4 for a description of gas phase chemistry). There are uncertainties in the GEIA emissions as well as in the transport of the monoterpenes out of the forested BL in the global model. There are also uncertainties regarding the conversion to condensable organic species and the potential for organic species other than monoterpenes to produce secondary organic aerosol (SOA). We explore the effect of changing the monoterpene emission rate by a factor of 10 to take account of uncertainties in SOA yields and precursor emissions. A comparison of observed and modelled growth rates during nucleation events suggests that the gas phase condensable organic concentration is consistent with emissions at the higher end, at least in Finland.

All condensable organic products are lumped together and treated as one species. In the version of GLOMAP that we use here the aerosol distribution has a single composition. Therefore, once the organic has condensed into the aerosol phase it is indistinguishable from other aerosol constituents (sulfate or sea-salt). No attempt is made to treat the chemical characteristics specific to organic mixtures or to model the change in hygroscopic behaviour and growth factors that occur due to the presence of organic compounds.

\subsection{Gas phase species}

We use the latest AEROCOM gridded emissions database for anthropogenic $\mathrm{SO}_{2}$ for the year 2000 (Cofala et al., 2005). Using GEIA 1985 emissions of $\mathrm{SO}_{2}$ (Benkovitz et al., 1996) leads to over-prediction of concentrations in Europe by about a factor 3. Oceanic dimethyl sulfide (DMS) emissions are calculated using the sea-surface concentrations from Kettle et al. (1999) and the sea-to-air transfer velocity of Liss and Merlivat (1986). Volcanic emissions of $\mathrm{SO}_{2}$ from continuously erupting volcanoes are from Andres and Kasgnoc (1998). Gas phase sulfuric acid is calculated using a simplified sulfur cycle scheme based on 7 reactions involving $\mathrm{SO}_{2}$, DMS, MSA and other minor species (Spracklen et al., 2005a).

As described in Sect. 2.3 the growth of newly formed as well as existing particles is greatly enhanced by condensation of oxidised organic compounds. We assume that these condensable products derive entirely from biogenic monoterpenes. The GEIA database categorizes emissions of biogenic VOCs into isoprene, terpenes, other reactive VOCs (ORVOCs), and other VOCs (OVOCs) (Guenther et al., 1995; Benkovitz et al., 1996). ORVOCs have lifetimes of less than 1 day and OVOCs have lifetimes longer than 1 day. OVOCs do not contribute to secondary aerosol formation (Griffin et al., 1999). The ORVOCs include a wide range of compounds some of which may give low volatility oxidation products whereas others have little or no potential to form SOA. This makes it difficult to include their contribution to aerosol formation in a global model and for this reason are not considered further in GLOMAP. Griffin et al. (1999) estimated that about $30 \%$ of combined OVOCS and ORVOCs may oxidise to low volatility products.

Only emissions of terpenes from the GEIA database (TERP.1A file) are considered. This database gives $1^{\circ} \times 1^{\circ}$ monthly mean emissions for 1990 . No attempt is made to modulate the monthly mean emissions depending on local environmental or meteorological factors such as temperature or light intensity. That is, emission rates are constant through the month and throughout the daily cycle. This may result in an underprediction of terpene emissions during the day (when emissions are observed to be greatest) and an overprediction during the night (when emissions are observed to be smallest). However, due to the uncertainties in the environmental drivers that control emission rates this simplification was thought to be justified.

The reactivity of the terpenes is assumed equal to that of $\alpha$ pinene, which is oxidised in the gas-phase through reaction with ozone, $\mathrm{OH}$ and $\mathrm{NO}_{3}$. Reaction rates are taken from Atkinson et al. (1989) and are listed in Table 2.

The oxidants $\mathrm{OH}, \mathrm{O}_{3}, \mathrm{HO}_{2}$ and $\mathrm{NO}_{3}$ are specified from separate TOMCAT full tropospheric chemistry runs and read in at 6-h intervals and linerally interpolated onto the model timestep.

\section{Design of the model experiments}

The model was initialised with an aerosol-free atmosphere on 1 January 2003 and spun up for 60 days before comparing the results with observations. This period is long enough for tropospheric aerosol concentrations to reach steady values (Spracklen et al., 2005a).

Several experiments were performed:

1. A run with only binary homogeneous nucleation (BHN) of sulfuric acid aerosol. This run allows us to quantify 
the atmospheric $\mathrm{CN}$ concentration when there are no anthropogenic primary particle emissions and no nucleation events in the BL.

2. A run with $\mathrm{BC}$ and $\mathrm{OC}$ primary anthropogenic emissions and BHN of sulfuric acid aerosol. This run is similar to that used in recent global aerosol model studies (e.g., Stier et al., 2005).

3. A run with BHN of sulfuric acid aerosol above the BL, primary $\mathrm{BC}$ and $\mathrm{OC}$, and $\mathrm{BL}$ nucleation events according to the parametrisation described in Sect. 2.2.

4. A run with BHN of sulfuric acid aerosol above the BL, $\mathrm{BL}$ nucleation events but no primary emissions of $\mathrm{BC}$ and OC.

Further sensitivity tests were then performed to quantify the effect of uncertainties in organic condensation, primary particle emissions, $\mathrm{SO}_{2}$ emissions, and the magnitude of the constant $k$ in Eq. (1).

\section{Comparison with observations}

\subsection{The observations}

The Quantification of Aerosol Nucleation in the European BL (QUEST) campaign was carried out at the SMEAR II (Station for Measuring Forest Ecosystem-Atmosphere Relations) field measurement station at Hyytiälä, Finland $\left(61^{\circ} 51^{\prime} \mathrm{N}, 24^{\circ} 17^{\prime} \mathrm{E}, 181 \mathrm{~m}\right.$ a.s.l.) in March and April 2003. We focus on these observations because of the supporting measurements of organic compounds, $\mathrm{SO}_{2}$, and sulfuric acid. The Hyytiälä station is located in an extended region of pine forest and during the selected period it experienced conditions ranging from remote continental to polluted continental, as defined by particle loadings and $\mathrm{SO}_{2}$ concentrations. $\mathrm{SO}_{2}$ varies between less than 100 pptv to greater than $1500 \mathrm{pptv}$ in air advected northwards from central Europe. This period is also characterised by days with strong nucleation (event days) and days with suppressed nucleation (nonevent days), and both are important in the evaluation of a particle formation model. Nucleation events are observed on typically $60-120$ days per year, which is similar to the frequency at many other continental locations (Kulmala et al., 2004a). Extensive analyses of these observations have been reported in previous studies (e.g., Mäkelä et al., 1997; Kulmala et al., 1998; Dal Maso et al., 2005).

Aerosol measurements were made using two parallel Differential Mobility Particle Sizer (DMPS) devices; the first classifying particles between 3 and $10 \mathrm{~nm}$ diameter and the second between 10 and $500 \mathrm{~nm}$ diameter (Aalto et al., 2001). Both devices sample air at $2 \mathrm{~m}$ above the ground with a time resolution of $10 \mathrm{~min}$. Gas-phase sulfuric acid was measured using a chemical ionization mass spectrometer (CIMS) (Laakso et al., 2004) calibrated against known sulfuric acid sources to determine rates of loss to reactor walls and flow lines. The CI-MS has a time resolution of $1 \mathrm{~s}$, however measurements were integrated over $60 \mathrm{~s}$ periods. The detection limit is $1 \times 10^{4} \mathrm{~cm}^{-3}$ (Laakso et al., 2004) with a reported accuracy of $\pm 31 \%$ (Boy et al., 2005).

Maximum mixed BL height at Hyytiälä during August 2001 was calculated as between 1000 and $2200 \mathrm{~m}$ (Spirig et al., 2004). Radio soundings launched at Hyytiälä on 4 April 1999 recorded maximum BL height of $2180 \mathrm{~m}$ (Nilsson et al., 2001). At Hyytiälä model mean BL height in March and April 2003 is $550 \mathrm{~m}$ and maximum BL height is about $2000 \mathrm{~m}$.

\subsection{Comparison with total particle concentrations and gas phase species}

Figure 1 compares modelled surface-layer gas phase species and total particle concentrations against observations at Hyytiälä for the 22-day period of the QUEST campaign. The observed CN concentration varies between $3 \times 10^{2}$ and $5 \times 10^{4} \mathrm{~cm}^{-3}$, with a mean of $4.6 \times 10^{3} \mathrm{~cm}^{-3}$. Concentration peaks centred on local midday indicate local particle formation and appear to account for much of the variability in concentration. However, without a model of particle number concentrations it is not possible to determine the extent to which these transient events contribute to what appears to be a background $\mathrm{CN}$ concentration of $\sim 1-3 \times 10^{3} \mathrm{~cm}^{-3}$.

Modelled $\mathrm{SO}_{2}$ (Fig. 1b) agrees well with the observations in the mean, and captures four obvious polluted periods, but fails to capture the fifth after day 97 . The resulting gas phase sulfuric acid concentrations (Fig. 1c) agree with the observations to typically within a factor 2 , which is similar to the agreement obtained in the constrained box model study of Boy et al. (2005). There are some days on which modelled $\mathrm{H}_{2} \mathrm{SO}_{4}$ is too high, and on these days the model predicts nucleation events when none was observed (e.g., days 78 and 96 in Fig. 1a). The reason for this discrepancy in $\mathrm{H}_{2} \mathrm{SO}_{4}$ is not clear, but may be related to our use of monthly mean $\mathrm{OH}$ fields, which are not affected by day-to-day variability in cloud cover. The modelled gas phase sulfuric acid concentration is based on modelled $\mathrm{SO}_{2}$ and the removal of the acid vapour to existing and nucleated particles, so combined errors in the model condensation sink and $\mathrm{SO}_{2}$ affect predicted $\mathrm{H}_{2} \mathrm{SO}_{4}$. We also note that after day $97 \mathrm{H}_{2} \mathrm{SO}_{4}$ is predicted rather well despite an undeprediction of the source gas $\mathrm{SO}_{2}$. It appears that the model underpredicts the general magnitude of this pollution event (both $\mathrm{SO}_{2}$ and condensation sink are lower than observed). Underprediction of both $\mathrm{SO}_{2}$ and condensation sink can lead to a reasonable prediction of $\mathrm{H}_{2} \mathrm{SO}_{4}$ because both the production and loss rates are similarly affected.

Figure $1 \mathrm{~d}$ also shows the observed and modelled gas phase concentration of monoterpenes and the modelled oxidised product that is assumed to condense on the particles. The modelled monoterpenes increase in a step-like way at day 91 

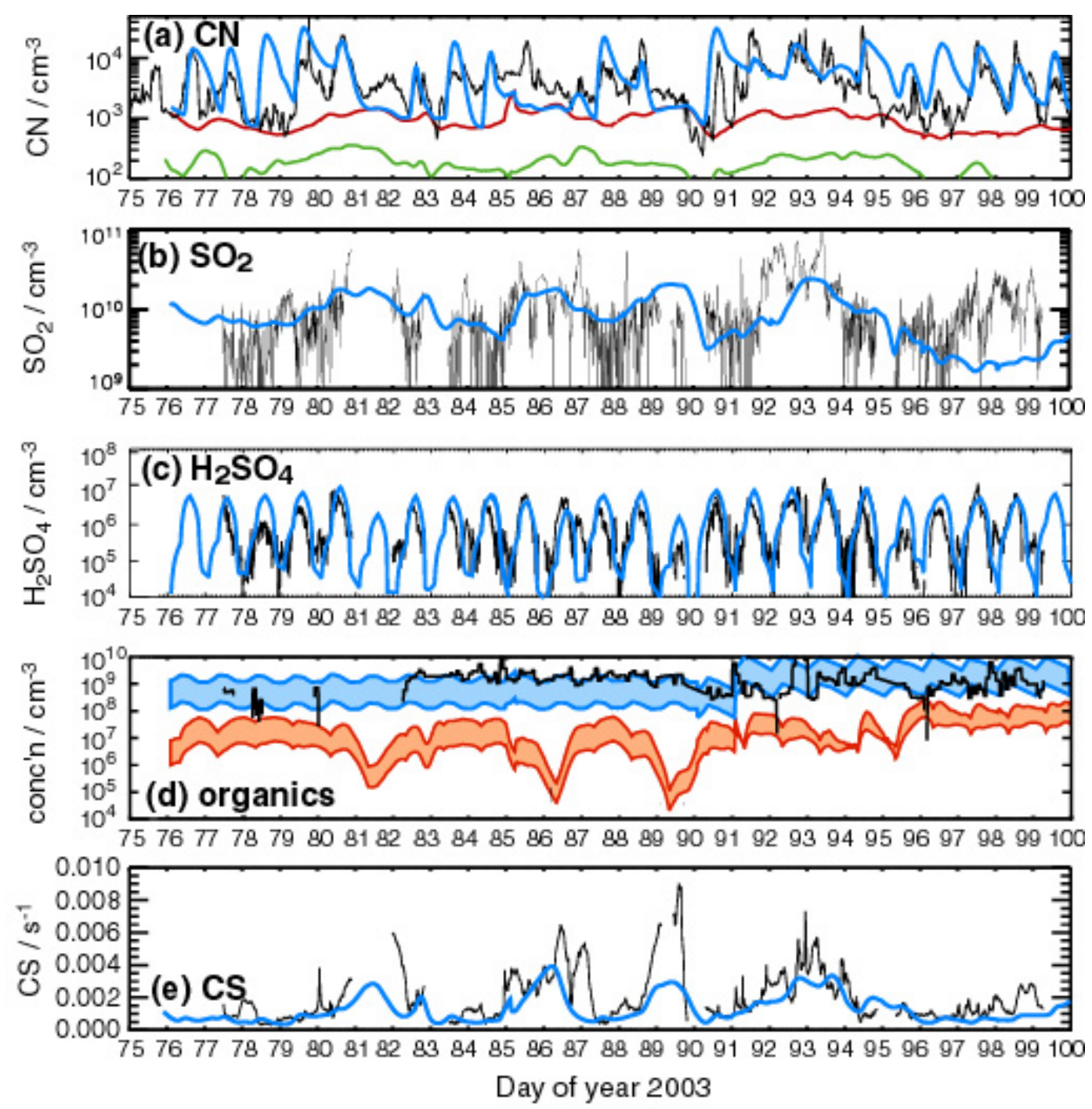

Fig. 1. Comparison of the global model with observations at Hyytiälä, Finland. (a) CN concentration (black - observations; green - model with binary homogeneous nucleation only; red - model with anthropogenic black and organic carbon primary emissions only; blue - model with primary emissions and particle formation). (b) Gas phase $\mathrm{SO}_{2}$ (black - observations; blue - model). (c) Gas phase sulfuric acid (black observations; blue - model). (d) Gas phase monoterpenes (black - observations; blue - model) and modelled condensable organics (orange). The organics are shown for standard GEIA emissions and for 10xGEIA emissions. (e) Condensation sink (black - observations; blue model).

due to the change in the monthly mean emissions. During March the modelled monoterpenes are about a factor 10 below the observations but in April the agreement with the observations is very good. The effect of uncertainties in organic precursors is explored below, but typically we find that total particle concentrations vary only by a factor $\sim 2$ for a factor 10 change in organics. Condensable vapour concentrations at Hyytiälä have been determined by a variety of techniques to be between $2.0 \times 107-1.3 \times 108 \mathrm{~cm}^{-3}$ (Kulmala et al., 2001; Dal Maso et al., 2002; Lehtinen et al., 2004; Korhonen et al., 2005). Model condensable vapour concentrations are about $0.5-2.0 \times 107 \mathrm{~cm}^{-3}$. This is a factor of $2-10$ lower than ob- served. As we show in Sect. 4.5, these condensable organic concentrations are lower than those required to explain observed particle growth rates.

We now compare observed and modelled surface-layer particle concentrations, a summary of which is provided in Table 3. Figure 1a shows that the model run with only binary homogeneous nucleation (BHN) of sulfuric acid-water produces CN concentrations of $100-200 \mathrm{~cm}^{-3}$, which is a factor 10 to 100 lower than observed. The BHN mechanism produces particles predominantly in the upper troposphere where it is cold and nucleation rates are high (Spracklen et al., 2005a, b). Typical concentrations in the 
Table 3. Comparison of observed and modelled particle number (dry diameter $>3 \mathrm{~nm}$ ) at Hyytiälä during the 22-day period of the QUEST campaign.

\begin{tabular}{llll}
\hline & Mean $/ 10^{3} \mathrm{~cm}^{-3}$ & Median $/ 10^{3} \mathrm{~cm}^{-3}$ & Maximum $/ 10^{4} \mathrm{~cm}^{-3}$ \\
\hline Observations & 4.6 & 3.2 & 5.3 \\
BHN model & 0.26 & 0.23 & 0.06 \\
BHN+BC/OC & 1.0 & 0.97 & 0.28 \\
BHN above BL+BC/OC+ & 8.1 & 5.5 & 4.5 \\
BL nucleation & & & \\
\hline
\end{tabular}

upper troposphere are $\sim 10^{4} \mathrm{~cm}^{-3}$ (at standard temperature and pressure). These particles subsequently mix down to the BL but are reduced in concentration due to coagulation and cloud scavenging. Our previous work (Spracklen et al., $2005 \mathrm{a}, \mathrm{b}$ ) shows that this source of particles produces a particle concentration of typically $100-200 \mathrm{~cm}^{-3}$ over much of the remote globe and is sufficient to explain a large fraction of MBL particle concentrations. Modelled surface CN concentrations reach around $1000 \mathrm{~cm}^{-3}$ from this UT source over the most polluted continental regions, but are clearly an insignificant source of particle number at this particular continental site.

The model run that includes primary emissions of anthropogenic black and organic carbon particles results in $\mathrm{CN}$ concentrations at Hyytiälä in the range $500-3000 \mathrm{~cm}^{-3}$ (red line). Primary particle concentrations are lower by a factor 30 than peak concentrations during some formation events. Outside the obvious particle formation periods (centred around midday) the primary particles help to explain $\mathrm{CN}$ concentrations during some periods but not others. Median particle concentrations in this model run are a factor 3.3 lower than observed.

The run including BL particle formation (blue line) captures the large amplitude increase in particle concentration associated with most of the events. The agreement with observations outside the obvious formation periods is also better. The fact that the rates of increase and decrease in modelled $\mathrm{CN}$ concentration during the events agree well with those observed suggests that particle formation, growth and coagulation rates are treated in a realistic way. There are some events (e.g., on day 76) where the modelled rate of decrease of particle concentration after an event is too slow. Examination of the temporal changes in the particle size distribution suggests that a sharp decrease in concentration can sometimes occur due to a change of airmass in the BL, which is not always captured by the global model. There is a tendency for the model to overestimate peak particle concentrations and median concentrations are $72 \%$ higher than observed (Table 3). However, inspection of Fig. 1 shows that the majority of the overpredicted maxima are on days when the model overpredicts $\mathrm{H}_{2} \mathrm{SO}_{4}$. This suggests that the assumption that $J^{*}$ depends on $\left[\mathrm{H}_{2} \mathrm{SO}_{4}\right]^{1}$ is approximately cor- rect but that the model has a tendency to overpredict $\mathrm{H}_{2} \mathrm{SO}_{4}$ maxima at Hyytiälä.

\subsection{Fraction of $\mathrm{CN}$ due to particle formation}

The differences between the model runs allow us to estimate the relative contribution of particle formation and primary particles to observed $\mathrm{CN}$, which has not previously been possible using the observations alone. During this 22-day period, the mean $\mathrm{CN}$ concentration in the run with particle formation is a factor 8 higher than with just primary emissions. Figure 1a also shows that particle formation often has a lasting impact on particle concentrations beyond the obvious transient formation periods. There is also evidence that particles produced in the events can dominate $\mathrm{CN}$ concentrations for several days. For example, on days 92-94 the observed CN concentration remains approximately a factor 510 higher than is produced by primary emissions alone, but this shortfall is accounted for by including particle formation in the model. During this period, the particle concentration after a midday event does not fall back to that of the primary particles, which implies that the transient particle formation events have a widespread and lasting influence on particle concentrations.

\subsection{Factors controlling particle formation}

These observations allow us to examine how the two key quantities in our model (the $\mathrm{H}_{2} \mathrm{SO}_{4}$ vapour concentration and the condensation sink) control particle formation, and whether the model is able to capture the observed dependence. Both quantities vary greatly between clean and polluted conditions, but their coupled effect is not straightforward, as previously noted (e.g., Gaydos et al., 2005; Fiedler et al., 2005). For example, on days 76-79 $\mathrm{SO}_{2}$ concentrations were $\sim 160$ pptv, typical of clean continental environments. These low $\mathrm{SO}_{2}$ concentrations limit the supply of $\mathrm{H}_{2} \mathrm{SO}_{4}$ vapour and thereby suppress particle formation on these days even though the condensation sink is low (Fig. 1d). This behaviour is well captured by the model. Typical polluted continental conditions occurred on days 9293, with observed $\mathrm{SO}_{2}$ concentrations exceeding 1500 pptv. Particle formation continued on these days despite a high 

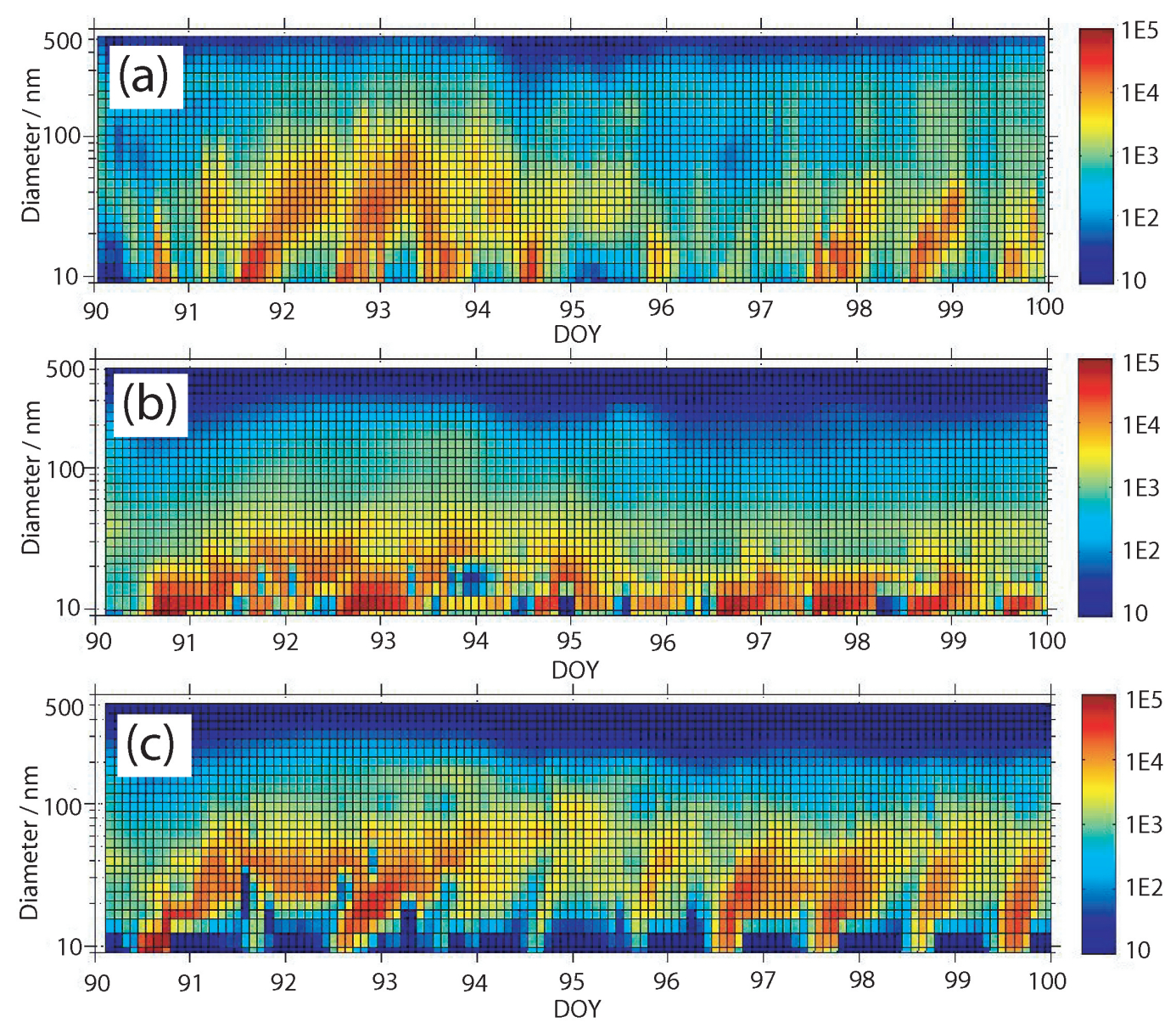

Fig. 2. Evolution of the particle size distribution (dN/dlogdp in $\mathrm{cm}^{-3}$ ) at Hyytiälä during March and April 2003. (a) Observations. (b) Model assuming GEIA monoterpene emissions. (c) Model assuming GEIA monoterpene emissions increased by a factor 10.

condensation sink, a phenomenon that has been observed at other polluted European sites (Fiedler et al., 2005). During other polluted periods (days 81-82, 86-87 and 89-90), the condensation sink is sufficiently high to suppress local particle formation over a wide range of $\mathrm{SO}_{2}$ concentrations. During these periods, $\mathrm{CN}$ concentrations can be explained quite well by primary particle emissions alone (Fig. 1a).

\subsection{Growth rates}

Figure 2 shows the observed and modelled evolution of the particle size distribution at Hyytiälä using two different organic emission scenarios (standard GEIA emissions and 13\% conversion to condensable products and a case with emissions increased by a factor 10). The temporal evolution of the size distribution is in excellent agreement with the observations for the high organic case. The newly formed particles obtain sizes of 50-60 nm, comparable to those observed. In contrast, the growth rate and final size of the particles is much too low in the run with the standard GEIA monoterpene emissions.
The effect of the higher organic emissions on total particle concentrations is shown in Fig. 3. Increasing organics reduces the particle concentration because the organics provide a larger condensation sink. In these simulations the organics do not contribute to growth between 1 and $3 \mathrm{~nm}$ so have no effect on the effective particle production rate at $3 \mathrm{~nm}$ other than through the condensation sink brought about by increased growth of all larger particles. We have also investigated the effect of allowing organics to contribute to growth from 2 to $3 \mathrm{~nm}$ (Kulmala et al., 2004b; Anttila et al., 2004). In the run with high organic emissions, allowing organicassisted growth between 2 and $3 \mathrm{~nm}$ enhances $J_{m}$ by at most a factor 2 during peak production periods. The greatest enhancements occur when $\mathrm{H}_{2} \mathrm{SO}_{4}$ concentrations are low, but particle formation rates are also low at these times. Overall, the average $\mathrm{CN}$ concentration is increased only by a factor 1.3 due to this process at this location. 


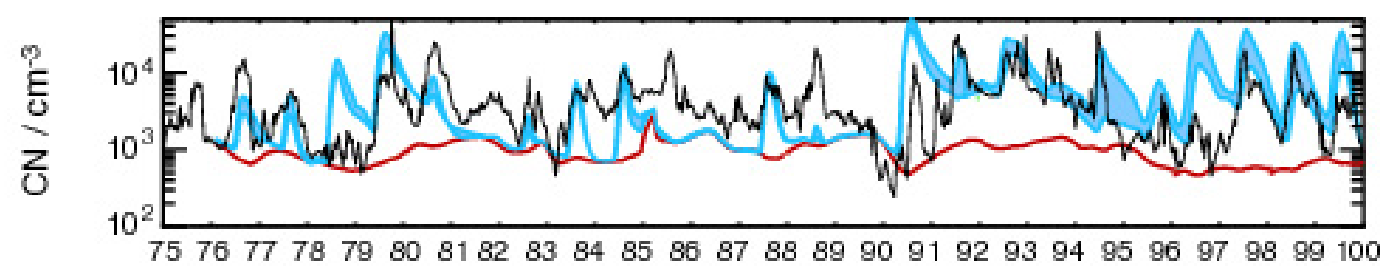

Fig. 3. The effect on modelled CN of increasing GEIA monoterpene emissions by a factor 10 compared to Fig. 1. Results are shown for the Hyytiälä observatory in Finland. The upper line of the shaded blue region is the result for low organics and the lower line the result for high organics. Red line - model CN with BC/OC emissions only. Black line - observed CN.
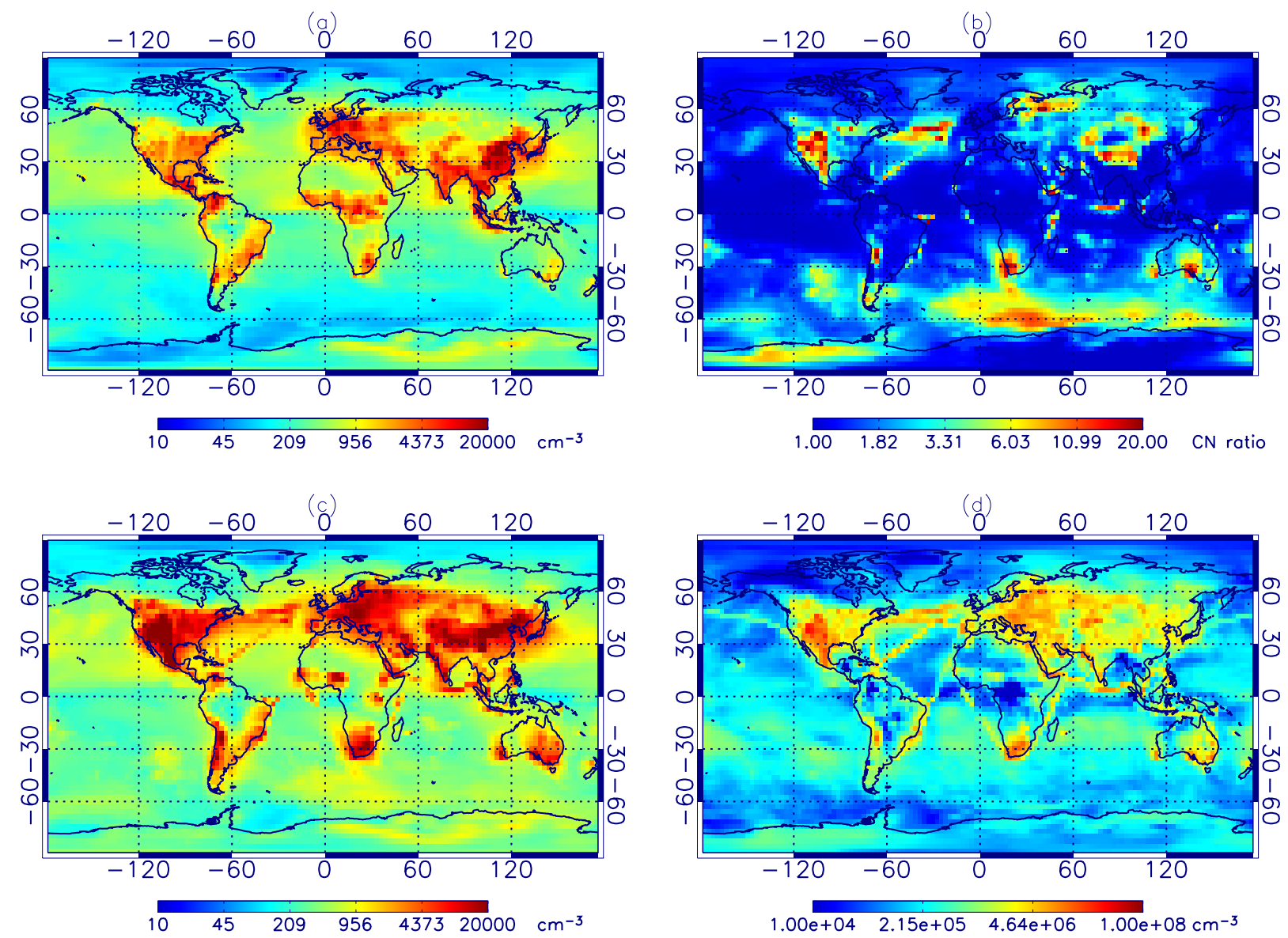

Fig. 4. Global distribution of predicted surface-level CN and sulfuric acid vapour for March 2003. (a) Modelled CN including only primary emissions. (b) Ratio of $\mathrm{CN}$ in the run with particle formation and primary emissions to the run with primary emissions only. (c) Modelled $\mathrm{CN}$ including only particle formation (no anthropogenic primary emissions). (d) Gas phase sulfuric acid.

\section{Large-scale predictions}

Before quantifying the sensitivity of these results to various assumptions in the model, we show what effect this particle formation mechanism has on the large scale aerosol field.

A complete evaluation of the model against observations from other surface sites is a major task that requires spinning up and running the global model for a number of specific periods. Such a model evaluation is beyond the scope of this first study. Nevertheless, having shown that the model captures much of the particle formation at a European site, it is interesting to examine how global variations in $\mathrm{H}_{2} \mathrm{SO}_{4}$ and condensation sink could affect particle formation if such a mechanism were to operate more widely. Predicted global fields also provide a useful reference against which we can determine the parts of the atmosphere where formation may be most important. Global calculations remain somewhat speculative at this stage and should be taken as a first 
prediction against which surface observations could in future be compared.

The enhancements in $\mathrm{CN}$ quantified in Fig. 1 are predicted by the model to occur over large regions. Figure 4a shows that the global distribution of modelled primary $\mathrm{CN}$ is dominated by high concentrations over polluted regions. However, the spatial pattern of the mean enhancement in concentration due to particle formation (Fig. $4 \mathrm{~b}$ ) is more complex as it is controlled by day-to-day patterns of $\mathrm{SO}_{2}$ concentration and condensation sink, as was apparent in Fig. 1. The formation events are predicted to enhance the monthly mean particle concentrations by a factor 15 over large regions of northern and central Eurasia, the western United States and Canada. Enhancements are typically less ( $\sim 30 \%$ to a factor 2) over parts of Europe, the eastern United States and parts of China.

Particle formation events occur in polluted continental regions with a frequency in the model that is broadly similar to that observed: one every two or three days (Birmili and Wiedensohler 2000; Birmili et al., 2000; Kulmala et al., 2004a). Modelled particle concentrations reach $6 \times 10^{4} \mathrm{~cm}^{-3}$ during events over central Europe, which is comparable to observed concentrations of $14 \times 10^{4} \mathrm{~cm}^{-3}$ at Melpitz $\left(51^{\circ} 32^{\prime} \mathrm{N}, 12^{\circ} 56^{\prime} \mathrm{E}\right.$, Birmili and Wiedensohler, 2000) and $4.5 \times 10^{4} \mathrm{~cm}^{-3}$ at Heidelberg $\left(49^{\circ} 23^{\prime} \mathrm{N}, 08^{\circ} 41^{\prime} \mathrm{E}\right.$, Fiedler et al., 2005). In central Europe, primary particle concentrations of between $2 \times 10^{3}$ and $1 \times 10^{4} \mathrm{~cm}^{-3}$ dominate total $\mathrm{CN}$. Enhancement of mean $\mathrm{CN}$ number due to particle formation events at Melpitz is a factor of 1.9. The model suggests that although particle formation does occur in polluted regions, particle concentrations in such regions are dominated by primary emissions.

The Amazon basin shows virtually no enhancement (Fig. 4b), which is consistent with the lack of evidence for particle formation events there (Kulmala et al., 2004a). In central Amazonia during March-April 1998 Zhou et al. (2002) observed regular occurrence of $30 \mathrm{~nm}$ sized particles but no evidence of smaller sized particles associated with local nucleation. They suggested that the most probable source of these $30 \mathrm{~nm}$ size particles was mixing from aloft. In our model, the reason for the lack of BL particle formation is the predicted low $\mathrm{SO}_{2}$ concentrations.

Over the oceans, enhancements of particle number can be seen along shipping lanes (in particular between the Panama Canal and East coast of the U.S.) caused by anthropogenic emissions of $\mathrm{SO}_{2}$. Little or no enhancement of particle concentration occurs over most remote areas including much of the tropics and the Pacific Ocean. Over the Southern Ocean, enhancement depends on the strength of the supermicron sea salt flux, which controls the condensation sink in the MBL. Estimates of sea salt flux vary by up to an order of magnitude. The results in Fig. 4 are for a model run using the sea salt scheme of Gong (2003), which calculates super-micron sea salt emissions at the lower end of other estimates. However, a run in which this flux was in- creased by a factor 10 led to a change in $\mathrm{CN}$ of only a few percent, which is consistent with our previous findings (Spracklen et al., 2005b). Enhancements of a factor 3-10 over the remote Southern Ocean $\left(30-70^{\circ} \mathrm{S}\right)$ results in CN concentrations of $\sim 250-1000 \mathrm{~cm}^{-3}$, in good agreement with observations. Many global aerosol models without particle formation events underpredict aerosol number in the Southern Ocean (Adams and Seinfeld, 2002; Easter et al., 2004; Spracklen et al., 2005a). However, the recent work of Pierce and Adams (2006) suggests that model underprediction of $\mathrm{CN}$ in the Southern Ocean could be due to neglect or under prediction of sub-micron sea salt emissions.

A closer inspection of the Southern Ocean model results shows that particle formation tends to be enhanced preferentially around the top of the BL, with a decrease in $\mathrm{CN}$ concentration by about a factor 2 from there down to the surface. We also note that a timeseries of particle formation at the sea surface (similar to Fig. 1) does not show any obvious particle bursts; rather, for extended periods of time the $\mathrm{CN}$ concentration is more generally enhanced. Based on our model results, it is possible that particle formation could contribute to $\mathrm{CN}$ at the sea surface. However, if formation rates peak at the top of the BL as we suggest here, it is possible that in observations these particles could be interpreted as aerosol entrained from the free troposphere, which is a well recognised source of MBL aerosol. Based on these preliminary results, we suggest that lower atmospheric particle formation cannot be excluded as a significant source of particles to the MBL. This possibility requires further investigation if we are to understand what controls the marine aerosol budget.

\section{Sensitivity studies}

We now examine the sensitivity of total particle number to changes in gaseous and primary particle emissions as well as the constant $k$ in Eq. (1).

\subsection{Sensitivity to primary emissions}

Primary particles contribute to the total particle surface area in the BL and thereby can affect the amplitude of nucleation events (through the parameter $\mathrm{CS}^{\prime}$ in Eq. 2). Figure 5 shows modelled CN concentrations at Hyytiälä for a run with particle formation events but without primary emissions. Some peak $\mathrm{CN}$ concentrations are now higher and additional peaks occur where previously the primary particles evidently suppressed nucleation. This response of $\mathrm{CN}$ to the removal of primary particles shows that primary and secondary particles are strongly coupled. The global $\mathrm{CN}$ distribution in this run is shown in Fig. 4c.

Figure 6 shows how the modelled European mean CN concentration responds to changes in emissions of primary particles. Two different sets of runs are shown: one with primary emissions only (no formation events), shown as the circles 


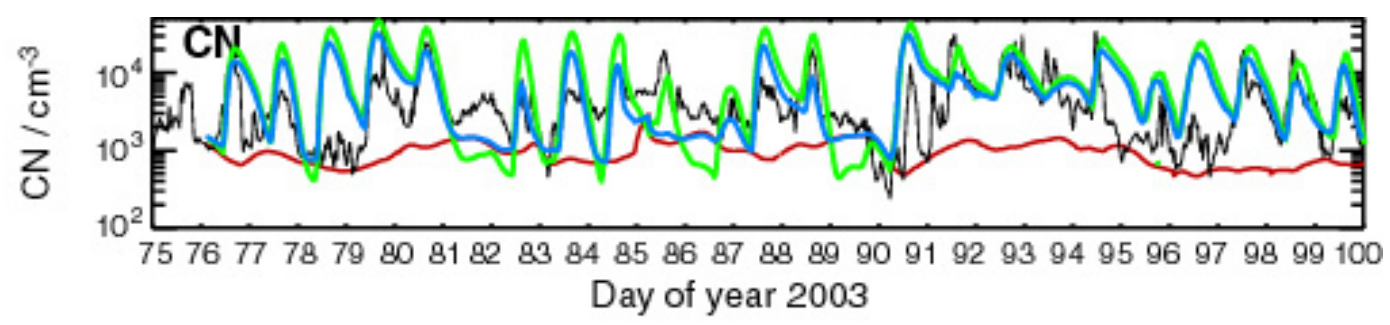

Fig. 5. The effect on modelled $\mathrm{CN}$ at Hyytiälä of removing primary emissions (green line) compared to the standard run with primary emissions (blue line, as in Fig. 1). Red line - model CN with BC/OC emissions only. Black line - observed CN.

for different emission rates of the primary particles, and another set of runs with both primary emissions and formation events, shown as squares for a range of primary emissions. Both sets of runs include binary homogeneous nucleation in the upper troposphere as well as sea spray emissions. These runs were performed with different $\mathrm{SO}_{2}$ emissions to those already shown. The baseline runs shown as circles and squares used 20\% GEIA emissions, which results in $\mathrm{SO}_{2}$ concentrations approximately equal to those from AEROCOM over Europe.

In the series of runs with primary emissions only (circles in Fig. 6) the present-day European mean $\mathrm{CN}$ concentration is predicted to be $6600 \mathrm{~cm}^{-3}, 14$ times higher than without any primary emissions. Globally, anthropogenic primary particles increase surface $\mathrm{CN}$ by a factor 2.8 . The $\mathrm{CN}$ concentration falls in direct proportion to the decreased anthropogenic primary emissions, reaching $\sim 500 \mathrm{~cm}^{-3}$ over Europe $\left(\sim 275 \mathrm{~cm}^{-3}\right.$ globally). This baseline European mean concentration of $500 \mathrm{~cm}^{-3}$ results primarily from transport of particles from the free troposphere into the boundary layer.

For the series of runs with both primary emissions and particle formation (squares in Fig. 6), changing the primary emissions leads to a non-linear change in $\mathrm{CN}$ due to changes in nucleation frequency and intensity as the condensation sink changes. Particle formation increases mean European CN concentrations from $6600 \mathrm{~cm}^{-3}$ to $9300 \mathrm{~cm}^{-3}$ with present-day primary emissions, a $40 \%$ increase. If the nucleation events remained unchanged as primary emissions were scaled back then the European mean $\mathrm{CN}$ concentration would be $\sim 3200 \mathrm{~cm}^{-3}$ when primary emissions reached zero (dashed line in Fig. 6), but instead they are predicted to be $\sim 13200 \mathrm{~cm}^{-3}$. These preliminary calculations take account of the response of particle formation to the existing particle surface area but neglect concomitant changes in $\mathrm{SO}_{2}$ emissions.

\subsection{Sensitivity to $\mathrm{SO}_{2}$ and organic emissions}

Gaydos et al. (2005) have shown using their model of ternary nucleation, that increases in $\mathrm{SO}_{2}$ could increase the surface area of existing particles and suppress particle formation.

We now examine the sensitivity of $\mathrm{CN}$ to emissions of $\mathrm{SO}_{2}$ using three different $\mathrm{SO}_{2}$ emission scenarios: $20 \%$ GEIA
(1985) $\mathrm{SO}_{2}$ emissions (as used in Sect. 6.1), 50\% of GEIA emissions, and standard (100\%) GEIA emissions. For each set of emissions we run the four standard experiments as described in Sect. 3. In the model runs with only BHN and $\mathrm{BC} / \mathrm{OC}$ emissions, increasing $\mathrm{SO}_{2}$ emissions by a factor of 5 (from 20\% GEIA emissions to standard GEIA emissions) increases particle number by only $\sim 5 \%$. With particle formation, the sensitivity to changing $\mathrm{SO}_{2}$ emissions depends on the magnitude of primary emissions, with model particle number being more sensitive to changing $\mathrm{SO}_{2}$ when primary $\mathrm{BC} / \mathrm{OC}$ emissions are higher. In the model run with particle formation and primary emissions of $\mathrm{BC} / \mathrm{OC}$, increasing $\mathrm{SO}_{2}$ emissions by a factor of 5 causes a $26 \%$ increase in particle number, whereas in the model run with no primary emissions the same increase in $\mathrm{SO}_{2}$ causes only a $14 \%$ increase in particle number. With primary emissions, changing $\mathrm{SO}_{2}$ emissions has little impact on the $\mathrm{CS}$, which is dominated by the primary emissions. Increase in $\mathrm{SO}_{2}$ causes an increase in available sulfuric acid and so an increase in total particle number. However, in the situation with no primary emissions, the condensation sink is now much lower, so increasing $\mathrm{SO}_{2}$ causes a significant increase in condensation sink. This increasing condensation sink reduces nucleation burst frequency/intensity and offsets some of the increase in particle number due to increasing $\mathrm{H}_{2} \mathrm{SO}_{4}$ concentrations. Overall, we find that European $\mathrm{CN}$ concentrations are far more sensitive to primary emissions (because of their effect on condensation sink) than they are to $\mathrm{SO}_{2}$ emissions.

Figure 3 showed the effect of a factor 10 change in organic emissions. The effect of increasing the organic emissions is to reduce the total particle concentration. Mean particle number at Hyytiälä over the QUEST period is reduced by about $25 \%$ for a factor 10 increase in organic emissions. This results because the organics increase the condensation sink by increasing the surface area of existing particles. The activation constant $k$, and hence the nucleation rate $J_{m}$ is likely to be dependent on the concentration of organic species (Kulmala et al., 2006). Our model runs use a constant value of $k$ and so ignore this dependence. Further work is required to establish the dependence of $J_{m}$ on species other than sulfuric acid. 


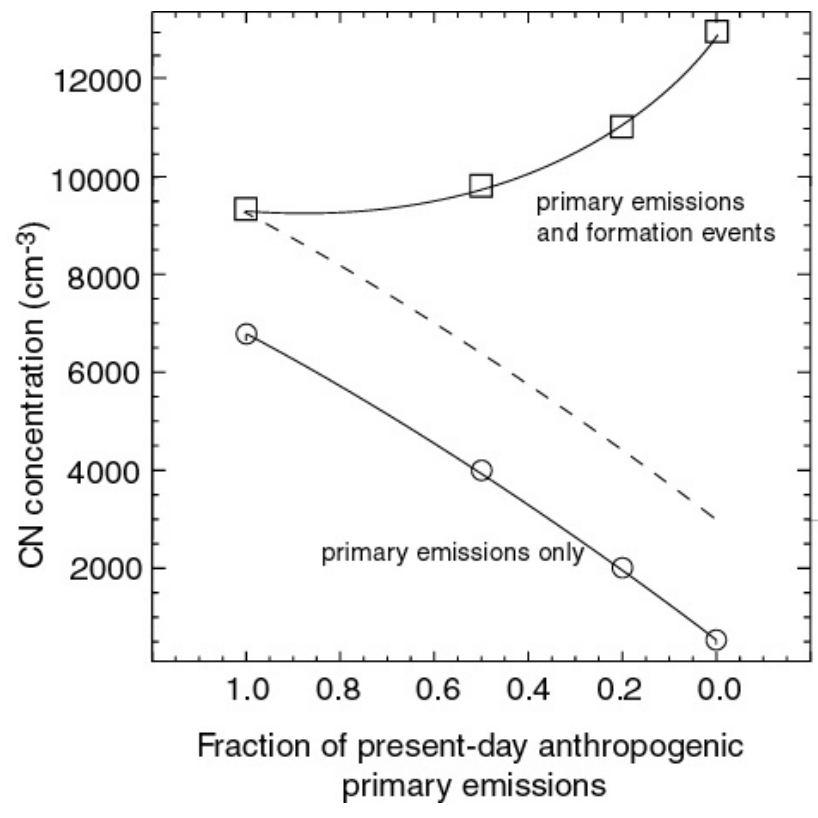

Fig. 6. The effect of primary particle emissions on mean surfacelevel European $\mathrm{CN}$ concentrations. Circles: results for model runs with primary emissions only. Squares: model runs with primary emissions and particle formation. The dashed line indicates how the $\mathrm{CN}$ concentration would change if the absolute production rate due to formation events remained constant as the primary emissions were reduced.

\subsection{Sensitivity to activation constant $k$}

The value of the activation constant, $k$, is likely to vary both temporally and spatially depending on the concentrations of gas phase species other than sulfuric acid (Kulmala et al., 2006). However, the quantitative nature of this dependence is so far unknown. Therefore in this work we have assumes a globally constant value of $k$. Figure 7 shows the effect of reducing $k$ by an order of magnitude. Mean model $\mathrm{CN}$ at Hyytiälä is reduced from $8.1 \times 10^{3} \mathrm{~cm}^{-3}$ to $4.1 \times 10^{3} \mathrm{~cm}^{-3}$ and maximum $\mathrm{CN}$ is reduced from $4.5 \times 10^{4} \mathrm{~cm}^{-4}$ to $2.0 \times 10^{4} \mathrm{~cm}^{-3}$. Over remote continental regions reducing $\mathrm{k}$ by an order of magnitude reduces mean model $\mathrm{CN}$ by a about a factor of 2 whereas over central Europe mean $\mathrm{CN}$ is reduced by about $25 \%$.

\section{Conclusions}

Many observations have been made of new particle formation in the atmospheric BL (Kulmala et al., 2004a). The very large number of particles formed, and the frequency of formation events at some locations, would suggest that particle formation makes an important contribution to the atmospheric aerosol number budget. However, no previous studies have attempted to quantify the large scale effects of particle formation or to separate the relative contributions of primary and secondary (nucleated) particles to $\mathrm{CN}$ concentrations. The recent development of global models including detailed treatments of aerosol microphysics and particle number concentrations now makes such a study possible.

We have included a new parametrisation of particle formation in the GLOMAP global aerosol microphysics model and have presented a first set of calculations in which we try to separate the contribution of primary emissions and new particle formation to global and regional $\mathrm{CN}$ concentrations. The new particles are assumed to be composed of sulfuric acid, water and oxidised biogenic organic compounds. The parametrisation is based on observations at a number of continental surface sites and has been designed specifically to capture the response of the particle formation rate to changes in $\mathrm{H}_{2} \mathrm{SO}_{4}$ and existing particle surface area (condensation sink) that is observed. The model has been evaluated in detail against observations from the SMEAR II station in Hyytiälä, Finland during March 2003. The predicted occurrence and intensity of formation events has been shown to be good for conditions ranging from remote to polluted continental.

We have some confidence in our global predictions for remote continental regions similar to southern Finland (i.e., remote and polluted continental locations, but away from immediate influence of urban emissions, for which Hyytiälä is not a good proxy). In more polluted conditions in central Europe, China and the E. USA our model results should be seen as a first attempt to predict the contribution of particle formation to the total particle concentration. Nevertheless, model-predicted peak $\mathrm{CN}$ concentrations and frequency of event occurrence are in reasonable agreement with observations from two central European sites.

The greatest enhancements in total particle concentration are predicted to occur over remote continental locations of Eurasia, the United States, South Africa and Australia. These regions are characterised by a moderate abundance of $\mathrm{H}_{2} \mathrm{SO}_{4}$ vapour from $\mathrm{SO}_{2}$ oxidation and low existing particle surface area. Particle formation has comparatively little impact on particle concentrations over the most polluted regions of $\mathrm{Eu}-$ rope, China and the eastern United States. In these regions, primary emissions tend to dominate particle number concentrations. Furthermore, a high existing particle surface area strongly suppresses particle formation because newly formed clusters are scavenged by coagulation before reaching observable sizes of $\sim 3 \mathrm{~nm}$ diameter. A surprising result is that this mechanism leads to enhancements in $\mathrm{CN}$ in the MBL of the North Atlantic and the remote Southern Ocean (in March at least). The cause in the North Atlantic is ship emissions of $\mathrm{SO}_{2}$. In the Southern Ocean, the DMS flux is high in March due to high wind speeds, so there is a relatively strong source of $\mathrm{H}_{2} \mathrm{SO}_{4}$ vapour. In the model, new particle formation tends to occur at the top of the MBL where the sea spray surface area is lower than at the surface. These particles are evidently mixed down to the surface, but do not leave a strong local signature of particle formation typical of continental regions. It needs to be considered whether such formation 


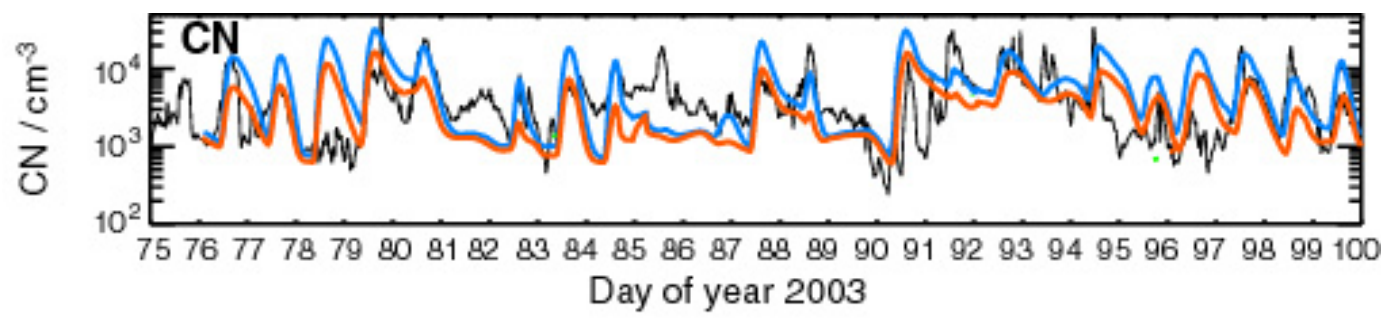

Fig. 7. The effect on modelled $\mathrm{CN}$ at Hyytiälä of reducing the nucleation rate constant $k$ (Eq. 1) by a factor 10. Red line - using $k / 10$. Blue line - using $k$. Black line - observations.

could be occurring and whether, in observations, the newly formed particles could have been lumped together with those entrained from the free troposphere.

Our results point towards an interesting coupling between primary and secondary particles. Primary particle emissions enhance the particle surface area in the lower atmosphere and therefore suppress new particle formation. In modern polluted environments, we have shown that $\mathrm{CN}$ are derived primarily from primary anthropogenic emissions, while in remote continental regions present day $\mathrm{CN}$ are dominated by secondary particle formation. We have shown that reductions in primary emissions could greatly enhance new particle formation, and hence $\mathrm{CN}$ concentrations. Despite the uncertainty in formation mechanism, this response is likely to be a fairly robust. Regardless of the cluster formation mechanism, the production rate of observable particles will depend on condensation sink, which will always act to scavenge newly formed clusters. This coupling means that the long-term change in total particle concentration is likely to be highly non-linear, depending in a complex way on primary particle and precursor gas emissions. The eventual effect of changes in emissions on cloud condensation nuclei and climate forcing is therefore not obvious, and needs to be investigated.

More work is clearly needed to evaluate the model at a range of sites, and this work is currently underway. There are some key aspects of the model that need evaluation against observations, laboratory data and process-level models. One example is the role of organics and ammonia in the cluster formation process. We have assumed that sub-nm clusters form at a rate proportional to the gas phase $\mathrm{H}_{2} \mathrm{SO}_{4}$ concentration (Kulmala et al., 2006; Sihto et al., 2006). Although this has been observed, it appears that ammonia may limit the formation rate in some environments (Gaydos et al., 2005). The role of organics may be difficult to detect based on observable $3 \mathrm{~nm}$ particle production if the same compounds contribute to cluster formation and their growth to $3 \mathrm{~nm}$, because both processes affect the apparent production rate at $3 \mathrm{~nm}$.

We have so far restricted our study to an analysis of total particle concentrations. Further work is needed to explore the possible implications for cloud condensation nuclei and direct radiative forcing. Observations suggest that newly formed particles can grow to the required size to affect these climate processes (Lihavainen et al., 2003; Laaksonen et al., 2005; Kerminen et al., 2005). However, a fuller study needs to take into account the relative contribution of primary and secondary particles and the effect of widespread particle formation on the average particle size, which controls cloud droplet activation (Dusek et al., 2006).

Acknowledgements. This work was supported by a $\mathrm{PhD}$ studentship for D. V. Spracklen from the UK Natural Environment Research Council. K. S. Carslaw acknowledges funding from the Finnish Academy that supported a visiting professorship at Helsinki and a Royal Society International Joint Project Grant (2005/R4-JP).

Edited by: A. Nenes

\section{References}

Aalto, P., Hameri, K., Becker, E., Weber, R., Salm, J., Mäkelä, J. M., Hoell, C., O’Dowd, C. D., Karlsson, H., Hansson, H. C., Vakeva, M., Koponen, I. K., Buzorius, G., and Kulmala, M.: Physical characterization of aerosol particles during nucleation events, Tellus Series B-Chem. Phys. Meteorol., 53(4), 344-358, 2001.

Adams, P. J. and Seinfeld, J. H.: Predicting global aerosol size distributions in general circulation models, J. Geophys. Res.Atmos., 107(D19), 4370, doi:10.1029/2001JD001010, 2002.

Andres, R. J. and Kasgnoc, A. D.: A time-averaged inventory of subaerial volcanic sulfur emissions, J. Geophys. Res.-Atmos., 103(D19), 25 251-25 261, 1998.

Anttila, T., Kerminen, V. M., Kulmala, M., Laaksonen, A., and O'Dowd, C. D.: Modelling the formation of organic particles in the atmosphere, Atmos. Chem. Phys., 4, 1071-1083, 2004, http://www.atmos-chem-phys.net/4/1071/2004/.

Atkinson, R., Baulch, D., Cox, A., Hampson Jr., R., Derr, J., and Troe, J.: Evaluated kinetics and photochemical data for atmospheric chemistry: Supplement III, J. Phys. Chem. Ref. Data, 88, 881-1097, 1989.

Benkovitz, C. M., Scholtz, M. T., Pacyna, J., Tarrason, L., Dignon, J., Voldner, E. C., Spiro, P. A., Logan, J. A., and Graedel, T. E.: Global gridded inventories of anthropogenic emissions of sulfur and nitrogen, J. Geophys. Res.-Atmos., 101(D22), 29239$29253,1996$. 
Binkowski, F. S. and Shankar, U.: The Regional Particulate Matter Model .1. Model description and preliminary results, J. Geophys. Res.-Atmos., 100(D12), 26 191-26 209, 1995.

Birmili, W. and Wiedensohler, A.: New particle formation in the continental boundary layer: Meteorological and gas phase parameter influence, Geophys. Res. Lett., 27(20), 3325-3328, 2000.

Birmili, W., Wiedensohler, A., Plass-Dulmer, C., and Berresheim, $\mathrm{H}$.: Evolution of newly formed aerosol particles in the continental boundary layer: A case study including $\mathrm{OH}$ and $\mathrm{H}_{2} \mathrm{SO}_{4}$ measurements, Geophys. Res. Lett., 27(15), 2205-2208, 2000.

Bond, T. C., Streets, D. G., Yarber, K. F., Nelson, S. M., Woo, J. H., and Klimont, Z.: A technology-based global inventory of black and organic carbon emissions from combustion, J. Geophys. Res.-Atmos., 109(D14), D14203, doi:10.1029/2003JD003697, 2004.

Boy, M., Kulmala, M., Ruuskanen, T. M., Pihlatie, M., Reissell, A., Aalto, P. P., Keronen, P., Dal Maso, M., Hellen, H., Hakola, H., Jansson, R., Hanke, M., and Arnold, F.: Sulfuric acid closure and contribution to nucleation mode particle growth, Atmos. Chem. Phys., 5, 863-878, 2005,

http://www.atmos-chem-phys.net/5/863/2005/.

Boy, M., Hellmuth, O., Korhonen, H., Nilsson, E. D., ReVelle, D., Turnipseed, A., Arnold, F., and Kulmala, M.: MALTE - model to predict new aerosol formation in the lower troposphere, Atmos. Chem. Phys., 6, 4499-4517, 2006,

http://www.atmos-chem-phys.net/6/4499/2006/.

Chipperfield, M. P., Cariolle, D., Simon, P., Ramaroson, R., and Lary, D. J.: A three-dimensional modeling study of trace species in the Arctic lower stratosphere during winter 1989-90, J. Geophys. Res., 98, 7199-7218, 1993.

Cofala, J., Amann, M., Klimont, Z., and Schöpp, W.: Scenarios of World Anthropogenic Emissions of SO2, NOx , and CO up to 2030, Internal report of the Transboundary Air Pollution Programme, International Institute for Applied Systems Analysis, Laxenburg, Austria, pp. 17, 2005.

Dal Maso, M., Kulmala, M., Lehtinen, K., Mäkelä, J., and Aalto, P.: Condensation and coagulation sinks and formation of nucleation mode particles in coastal and boreal forest boundary layers, J. Geophys. Res.-Atmos., 107, 8097, doi:10.1029/2001JD001053, 2002.

Dal Maso, M., Kulmala, M., Riipinen, I., Wagner, R., Hussein, T., Aalto, P. P., and Lehtinen, K. E. J.: Formation and growth of fresh atmospheric aerosols: eight years of aerosol size distribution data from SMEAR II, Hyytiala, Finland, Boreal Environ. Res., 10(5), 323-336, 2005.

Dentener, F., Kinne, S., Bond, T., Boucher, O., Cofala, J., Generoso, S., Ginoux, P., Gong, S., Hoelzemann, J., Ito, A., Marelli, L., Penner, J., Putaud, J.-P., Textor, C., Schulz, M., van der Werf, G., and Wilson, J.: Emissions of primary aerosol and precursor gases in the years 2000 and 1750 - prescribed data-sets for AeroCom, Atmos. Chem. Phys., 6, 4321-4344, 2006, http://www.atmos-chem-phys.net/6/4321/2006/.

Dusek, U., Frank, G. P., Hildebrandt, L., Curtius, J., Schneider, J., Walter, S., Chand, D., Drewnick, F., Hings, S., Jung, D., Borrmann, S., and Andreae, M. O.: Size matters more than chemistry for cloud-nucleating ability of aerosol particles, Science, 312(5778), 1375-1378, 2006.

Easter, R. C., Ghan, S. J., Zhang, Y., Saylor, R. D., Chapman, E. G.,
Laulainen, N. S., Abdul-Razzak, H., Leung, L. R., Bian, X. D., and Zaveri, R. A.: MIRAGE: Model description and evaluation of aerosols and trace gases, J. Geophys. Res.-Atmos., 109(D20), D20210, doi:10.1029/2004JD004571, 2004.

Fiedler, V., Dal Maso, M., Boy, M., Aufmhoff, H., Hoffmann, J., Schuck, T., Birmili, W., Hanke, M., Uecker, J., Arnold, F., and Kulmala, M.: The contribution of sulfuric acid to atmospheric particle formation and growth: a comparison between boundary layers in Northern and Central Europe, Atmos. Chem. Phys,, 5, 1773-1785, 2005.

Fuchs, N. A. and Sutugin, A. G.: Highly dispersed aerosols, in: Topics in current aerosol research, edited by: Hidy, G. M. and Brock, J. R., New York, Pergamon, 1971.

Gaydos, T. M., Stanier, C. O., and Pandis, S. N.: Modeling of in situ ultrafine atmospheric particle formation in the eastern United States, J. Geophys. Res.-Atmos., 110(D7), D07S12, doi:10.1029/2004JD004683, 2005.

Ghan, S. J., Easter, R. C., Chapman, E. G., Abdul-Razzak, H., Zhang, Y., Leung, L. R., Laulainen, N. S., Saylor, R. D., and Zaveri, R. A.: A physically based estimate of radiative forcing by anthropogenic sulfate aerosol, J. Geophys. Res.-Atmos., 106(D6), 5279-5293, 2001.

Gong, S. L.: A parameterization of sea-salt aerosol source function for sub- and super-micron particles, Global Biogeochem. Cycles, 17(4), 1097, doi:10.1029/2003GB002079, 2003.

Gong, S., Barrie, L., Blanchet, J.-P., von Salzen, K., Lohmann, U., Lesins, G., Spacek, L., Zhang, L., Girard, E., Lin, H., Leaitch, R., Leighton, H., Chylek, P., and Huang, P.: Canadian Aerosol Module: A size-segregated simulation of atmospheric aerosol processes for climate and air quality models 1 . Module development, J. Geophys. Res.-Atmos., 108, 4007, doi:10.1029/2001JD002 002, 2003.

Griffin, R. J., Cocker, D. R., Flagan, R. C., and Seinfeld, J. H.: Organic aerosol formation from the oxidation of biogenic hydrocarbons, J. Geophys. Res.-Atmos., 104(D3), 3555-3567, 1999.

Guenther, A., Hewitt, C. N., Erickson, D., Fall, R., Geron, C., Graedel, T., Harley, P., Klinger, L., Lerdau, M., McKay, W. A., Pierce, T., Scholes, B., Steinbrecher, R., Tallamraju, R., Taylor, J., and Zimmerman, P.: A Global-Model of Natural Volatile Organic-Compound Emissions, J. Geophys. Res.Atmos., 100(D5), 8873-8892, 1995.

Hirsikko, A., Laakso, L., Horrak, U., Aalto, P. P., Kerminen, V. M., and Kulmala, M.: Annual and size dependent variation of growth rates and ion concentrations in boreal forest, Boreal Environ. Res., 10(5), 357-369, 2005.

Holtslag, A. and Boville, B.: Local versus nonlocal boundary layer diffusion in a globl climate model, J. Climate, 6, 1825-1842, 1993.

Jackervoirol, A. and Mirabel, P.: Heteromolecular Nucleation in the Sulfuric Acid-Water System, Atmos. Environ., 23(9), 20532057, 1989.

Kerminen, V. M. and Kulmala, M.: Analytical formulae connecting the "real" and the "apparent" nucleation rate and the nuclei number concentration for atmospheric nucleation events, J. Aerosol Sci., 33(4), 609-622, 2002.

Kerminen, V. M. and Wexler, A. S.: Particle Formation Due to $\mathrm{SO}_{2}$ Oxidation and High Relative-Humidity in the Remote Marine Boundary-Layer, J. Geophys. Res.-Atmos., 99(D12), $25607-$ 25 614, 1994. 
Kerminen, V. M., Lihavainen, H., Komppula, M., Viisanen, Y., and Kulmala, M.: Direct observational evidence linking atmospheric aerosol formation and cloud droplet activation, Geophys. Res. Lett., 32(14), L14803, doi:10.1029/20005GL023130, 2005.

Kettle, A. J., Andreae, M. O., Amouroux, D., Andreae, T. W., Bates, T. S., Berresheim, H., Bingemer, H., Boniforti, R., Curran, M. A. J., DiTullio, G. R., Helas, G., Jones, G. B., Keller, M. D., Kiene, R. P., Leck, C., Levasseur, M., Malin, G., Maspero, M., Matrai, P., McTaggart, A. R., Mihalopoulos, N., Nguyen, B. C., Novo, A., Putaud, J. P., Rapsomanikis, S., Roberts, G., Schebeske, G., Sharma, S., Simo, R., Staubes, R., Turner, S., and Uher, G.: A global database of sea surface dimethylsulfide (DMS) measurements and a procedure to predict sea surface DMS as a function of latitude, longitude, and month, Global Biogeochem. Cycles, 13(2), 399-444, 1999.

Koponen, I. K., Virkkula, A., Hillamo, R., Kerminen, V. M., and Kulmala, M.: Number size distributions and concentrations of the continental summer aerosols in Queen Maud Land, Antarctica, J. Geophys. Res.-Atmos., 108(D18), 4587, doi:10.1029/2003JD003614, 2003.

Korhonen, H., Kerminen, V.-M., and Kulmala, M.: Development and application of a new analytical method to estimate the condensable vapor concentration in the atmosphere, J. Geophys. Res.-Atmos., 110, D05201, doi:10.1029/2004JD005458, 2005.

Kulmala, M., Laaksonen, A., and Pirjola, L.: Parameterizations for sulfuric acid/water nucleation rates, J. Geophys. Res.-Atmos., 103(D7), 8301-8307, 1998.

Kulmala, M., Dal Maso, M., Mäkelä, J., Pirjola, L., Vakeva, M., Aalto, P., Miikkulainen, P., Hameri, K., and O'Dowd, C.: On the formation, growth and composition of nucleation mode particles, Tellus, Ser. B, 53B, 479-490, 2001.

Kulmala, M., Vehkamäki, H., Petajda, T., Dal Maso, M., Lauri, A., Kerminen, V. M., Birmili, W., and McMurry, P. H.: Formation and growth rates of ultrafine atmospheric particles: a review of observations, J. Aerosol Sci., 35(2), 143-176, 2004a.

Kulmala, M., Kerminen, V. M., Anttila, T., Laaksonen, A., and O'Dowd, C. D.: Organic aerosol formation via sulfate cluster activation, J. Geophys. Res.-Atmos., 109(D4), D04205, doi:10.1029/2003JD003961, 2004b.

Kulmala, M., Lehtinen, K. E. J., and Laaksonen, A.: Cluster activation theory as an explanation of the linear dependence between formation rate of $3 \mathrm{~nm}$ particles and sulfuric acid concentration, Atmos. Chem. Phys., 6, 787-793, 2006,

http://www.atmos-chem-phys.net/6/787/2006/.

Laakso, L., Petaja, T., Lehtinen, K. E. J., Kulmala, M., Paatero, J., Horrak, U., Tammet, H., and Joutsensaari, J.: Ion production rate in a boreal forest based on ion, particle and radiation measurements, Atmos. Chem. Phys., 4, 1933-1943, 2004, http://www.atmos-chem-phys.net/4/1933/2004/.

Laaksonen, A., Hamed, A., Joutsensaari, J., Hiltunen, L., Cavalli, F., Junkermann, W., Asmi, A., Fuzzi, S., and Facchini, M. C.: Cloud condensation nucleus production from nucleation events at a highly polluted region, Geophys. Res. Lett., 32(6), L06812, doi:10.1029/2004GL022092, 2005.

Lehtinen, K. E. J. and Kulmala, M.: A model for particle formation and growth in the atmosphere with molecular resolution in size, Atmos. Chem. Phys., 3, 251-257, 2003, http://www.atmos-chem-phys.net/3/251/2003/.

Lehtinen, K. E. J. Rannik, U., Petaja, T., Kulmala, M., and Hari,
P.: Nucleation rates and vapour concentration estimations using a least squares aerosol dynamics method, J. Geophys. Res.Atmos., 109, doi:10.1029/2004JD004893, 2004.

Lihavainen, H., Kerminen, V. M., Komppula, M., Hatakka, J., Aaltonen, V., Kulmala, M., and Viisanen, Y.: Production of "potential" cloud condensation nuclei associated with atmospheric newparticle formation in northern Finland, J. Geophys. Res.-Atmos., 108(D24), 4782, doi:10.1029/2003JD003887, 2003.

Liss, P. and Merlivat, L.: Air-sea gas exchange rates: Introduction and synthesis, in: The Role of Air-Sea Exchange in Geochemical Cycling, edited by: Reidel, D.. 113-127, Norwell, Mass., 1986.

Mäkelä, J. M., Aalto, P., Jokinen, V., Pohja, T., Nissinen, A., Palmroth, S., Markkanen, T., Seitsonen, K., Lihavainen, H., and Kulmala, M.: Observations of ultrafine aerosol particle formation and growth in boreal forest, Geophys. Res. Lett., 24(10), 12191222, 1997.

McMurry, P., Fink, M., Sakurai, H., Stolzenburg, M., Mauldin III, R., Smith, J., Eisele, F., Moore, K., Sjostedt, S., Tanner, D., Huey, L., Nowak, J., Edgerton, E., and Voisin, D.: A criterion for new particle formation in the sulfur-rich Atlanta atmosphere, J. Geophys. Res.-Atmos., 110, D22S02, doi:10.1029/2005JD005901, 2005.

Napari, I., Noppel, M., Vehkamäki, H., and Kulmala, M.: Parametrization of ternary nucleation rates for H2SO4-NH3H2O vapors, J. Geophys. Res.-Atmos., 107(D19), 4381, doi:10.1029/2002JD002132, 2002.

Nilsson, E., Rannik, U., Kulmala, M., Buzorius, G., and O Dowd, C.: Effects of continental boundary layer evolution, convection, turbulence and entrainment, on aerosol formation, Tellus, 53B, 441-461, 2001.

O’Dowd, C., McFiggans, G., Creasey, D. J., Pirjola, L., Hoell, C., Smith, M. H., Allan, B. J., Plane, J. M. C., Heard, D. E., Lee, J. D., Pilling, M. J., and Kulmala, M.: On the photochemical production of new particles in the coastal boundary layer, Geophys. Res. Lett., 26(12), 1707-1710, 1999.

Petzold, A., Fiebig, M., Flentje, H., Keil, A., Leiterer, U., Schroder, F., Stifter, A., Wendisch, M., and Wendling, P.: Vertical variability of aerosol properties observed at a continental site during the Lindenberg Aerosol Characterization Experiment (LACE 98), J. Geophys. Res.-Atmos., 107(D21), 8128, doi:10.1029/2001JD001043, 2002.

Pierce, J. R. and Adams, P. J.: Global evaluation of CCN formation by direct emission of sea salt and growth of ultrafine sea salt, J. Geophys. Res.-Atmos., 111(D6), D06203, doi:10.1029/2005JD006186, 2006.

Prather, M.: Numerical Advection by Conservation of SecondOrder Moments, J. Geophys. Res.-Atmos., 91, 6671-6681, 1986.

Rodriguez, M. A. and Dabdub, D.: A modeling study of size- and chemically resolved aerosol thermodynamics in a global chemical transport model, J. Geophys. Res.-Atmos., 109(D2), D02203, doi:10.1029/2003JD003639, 2004.

Schroder, F., Karcher, B., Fiebig, M., and Petzold, A.: Aerosol states in the free troposphere at northern midlatitudes, J. Geophys. Res.-Atmos., 107(D21), 8126, doi:10.1029/2000JD000194, 2002.

Sihto, S.-L., Kulmala, M., Kerminen, V.-M., Dal Maso, M., Petäjä, T., Riipinen, I., Korhonen, H., Arnold, F., Janson, R., Boy, M., Laaksonen, A., and Lehtinen, K. E. J.: Atmospheric sulfuric acid and aerosol formation: implications from atmospheric mea- 
surements for nucleation and early growth mechanisms, Atmos. Chem. Phys., 6, 4079-4091, 2006,

http://www.atmos-chem-phys.net/6/4079/2006/.

Spirig, C., Guenther, A., Greenberg, J., Calanca, P., and Tarvainen, V.: Tethered balloon measurements of biogenic volatile organic compounds at a Boreal forest site, Atmos. Chem. Phys., 4, 215229, 2004, http://www.atmos-chem-phys.net/4/215/2004/.

Spracklen, D. V., Pringle, K. J., Carslaw, K. S., Chipperfield, M. P., and Mann, G. W.: A global off-line model of size-resolved aerosol microphysics: I. Model development and prediction of aerosol properties, Atmos. Chem. Phys., 5, 2227-2252, 2005 a.

Spracklen, D. V., Pringle, K. J., Carslaw, K. S., Chipperfield, M. P., and Mann, G. W.: A global off-line model of size-resolved aerosol microphysics: II. Identification of key uncertainties, Atmos. Chem. Phys., 5, 3233-3250, 2005 b.

Stier, P., Feichter, J., Kinne, S., Kloster, S., Vignati, E., Wilson, J., Ganzeveld, L., Tegen, I., Werner, M., Balkanski, Y., Schulz, M., Boucher, O., Minikin, A., and Petzold, A.: The aerosolclimate model ECHAM5-HAM, Atmos. Chem. Phys., 5, 11251156, 2005, http://www.atmos-chem-phys.net/5/1125/2005/.

Stockwell, D. Z. and Chipperfield, M. P.: A tropospheric chemicaltransport model: Development and validation of the model transport schemes, J. Geophys. Res., 125, 1747-1783, 1999.

Tammet, H. and Kulmala, M.: Simulation tool for atmospheric aerosol nucleation bursts, J. Aerosol Sci., 36(2), 173-196, 2005.

Tiedtke, M.: A comprehensive mass flux scheme for cumulus parameterization in large scale models, Mon. Wea. Rev., 117, 1779-1800, 1989.

Tunved, P., Strom, J., and Hansson, H. C.: An investigation of processes controlling the evolution of the boundary layer aerosol size distribution properties at the Swedish background station Aspvreten, Atmos. Chem. Phys., 4, 2581-2592, 2004, http://www.atmos-chem-phys.net/4/2581/2004/.

Tunved, P., Hansson, H. C., Kerminen, V. M., Strom, J., Dal Maso, M., Lihavainen, H., Viisanen, Y., Aalto, P. P., Komppula, M., and Kulmala, M.: High natural aerosol loading over boreal forests, Science, 312(5771), 261-263, 2006.

van der Werf, G. R., Randerson, J. T., Collatz, G. J., and Giglio, L.: Carbon emissions from fires in tropical and subtropical ecosystems, Global Change Biol., 9(4), 547-562, 2003.

VanReken, T. M., Ng, N. L., Flagan, R. C., and Seinfeld, J. H.: Cloud condensation nucleus activation properties of biogenic secondary organic aerosol, J. Geophys. Res., 110, D07206, doi:10.1029/2004JD005465, 2005.
Vehkamäki, H., Kulmala, M., Napari, I., Lehtinen, K. E. J., Timmreck, C., Noppel, M. and Laaksonen, A.: An improved parameterization for sulfuric acid-water nucleation rates for tropospheric and stratospheric conditions, J. Geophys. Res.-Atmos., 107(D22), 4622, doi:10.1029/2002JD002184, 2002.

Vehkamäki, H., Dal Maso, M., Hussein, T., Flanagan, R., Hyvarinen, A., Lauros, J., Merikanto, J., Monkkonen, P., Pihlatie, M., Salminen, K., Sogacheva, L., Thum, T., Ruuskanen, T. M., Keronen, P., Aalto, P. P., Hari, P., Lehtinen, K. E. J., Rannik, U., and Kulmala, M.: Atmospheric particle formation events at Varrio measurement station in Finnish Lapland 1998-2002, Atmos. Chem. Phys., 4, 2015-2023, 2004, http://www.atmos-chem-phys.net/4/2015/2004/.

Vignati, E., Wilson, J., and Stier, P.: M7: An efficient sizeresolved aerosol microphysics module for large-scale aerosol transport models, J. Geophys. Res.-Atmos., 109(D22), D22202, doi:10.1029/2003JD004485, 2004.

von Salzen, K., Leighton, H. G., Ariya, P. A., Barrie, L. A., Gong, S. L., Blanchet, J. P., Spacek, L., Lohmann, U., and Kleinman, L. I.: Sensitivity of sulphate aerosol size distributions and CCN concentrations over North America to SOx emissions and $\mathrm{H}_{2} \mathrm{O}_{2}$ concentrations, J. Geophys. Res.-Atmos., 105(D8), 9741-9765, 2000.

Wang, K. Y., Pyle, J. A., Sanderson, M. G., and Bridgeman, C.: Implementation of a convective atmospheric boundary layer scheme in a tropospheric chemistry transport model , J. Geophys. Res.Atmos, 104(D19), 23 729-23 745, 1999.

Weber, R. J., Marti, J. J., McMurry, P. H., Eisele, F. L., Tanner, D. J., and Jefferson, A.: Measured atmospheric new particle formation rates: Implications for nucleation mechanisms, Chem. Eng. Commun., 151, 53-64, 1996.

Yu, S. C., Kasibhatla, P. S., Wright, D. L., Schwartz, S. E., McGraw, R., and Deng, A. J.: Moment-based simulation of microphysical properties of sulfate aerosols in the eastern United States: Model description, evaluation, and regional analysis, J. Geophys. Res.Atmos., 108(D12), 4353, doi:10.1029/2002JD002890, 2003.

Zhou, J. C., Swietlicki, E., Hansson, H. C., and Artaxo, P.: Submicrometer aerosol particle size distribution and hygroscopic growth measured in the Amazon rain forest during the wet season, J. Geophys. Res.-Atmos., 107(D20), 8055, doi:10.1029/2000JD000203, 2002. 